\title{
Optimizing Energy - The Epistemology of Primitive Economic Man
}

\author{
Bryan Hockett \\ Bureau of Land Management, Nevada State Office \\ USA
}

\section{Introduction}

We are certainly not to relinquish the evidence of experiments for the sake of dreams and vain fictions of our own devising...

Isaac Newton (1687)

My goal in writing this essay is to provide a broad history of ideas related to human nutritional ecology. The central concept of nutritional ecology is that proper human fetal development, as well as maternal body maintenance before, during, and following pregnancy require a diverse suite of both energy-providing macronutrients (carbohydrates, fats, and proteins) and non-caloric micronutrients (vitamins, minerals, and water) (Hockett and Haws 2003, 2005). As a result, past human foragers who consistently consumed a relatively diverse diet should have set the nutritional framework that may have sparked increases in their population size and density. In contrast, restricted diets are unlikely to be associated with demographic pulses in ancient foraging societies.

By definition macronutrients (energy-producing carbohydrates, fats, and proteins) must be consumed in relatively large quantities compared to micronutrients (non-caloric vitamins and minerals), but this does not mean that the energy producing nutrients are more important to human health than the non-caloric nutrients, including water. A lack of vitamin-A in a human diet would leave a person as dead as one who starved to death through chronic energy deficiency. Importantly, there is not a single food group that provides all of the essential macro- and micronutrients necessary for proper fetal development, maternal health during and following pregnancy, and later growth and development of the individual (Ashworth and Antipatis, 2001; Fall et al., 2003; Ramakrishnan 1999). Humans can survive on restricted diets but these typically cause the over-consumption of certain critical nutrients and the under-consumption of others, which in turn has been shown to negatively impact mortality rates. They also create a host of potential body and mind health problems, particularly if protein is the major energy source consumed rather than carbohydrates (see also Hockett 2011). These facts, however, do not necessarily mean that ancient human foragers were engaged in the active pursuit of a balanced diet (maximizing essential nutrient diversity). Selection, however, may have exerted a greater role upon human societies at particular moments in space and time because of differences in dietary intake. 
The basis for a broad theoretical framework of human nutritional ecology may be presented as a series of questions: (1) what are the nutritional requirements for proper human fetal growth and development?; (2) what are the nutritional requirements for pregnant females before, during, and following pregnancy in order to ensure long-term maternal health?; (3) how can these nutritional requirements be obtained in the foods available to various human societies in space and time?; (4) what are the demographic consequences of underconsuming specific nutrients and over-consuming others?; and (5) could differences in the consumption of the variety of macro- and micronutrients have lead to, or at least contributed to, population expansions, declines, and replacements in the past?

Nutritional influences on human evolution must focus on both macronutrients and micronutrients to be meaningful, and nutritional ecology as a broad theoretical model should be developed with this holistic interpretive framework in mind (Hockett and Haws 2005:25, Table 1; Figure 1). Models that focus only on macronutrients, or that give paramount importance to energy as an explanatory framework (e.g., Broughton et al., 2011) reduce data to the point that meaningful interpretations of the past are an unlikely outcome.

The nutrition facts as we know them today, namely that diverse essential nutrient intake lowers infant and maternal mortality rates, are no revelation to anthropology and archaeology. There is a relatively large, anthropologically-oriented literature that has been published on human nutrition over the past 75 years (e.g., Arnott, 1976; Eaton et al., 1988; Harding and Teleki, 1981; Harris and Ross, 1987; Jenike, 2001; Kehoe and Giletti, 1981; Newman, 1962; Quin, 1959; Richards, 1932; Schwarcz and Shoeninger, 1991; Stini, 1971; Underwood, 1975; Vayda, 1970; Wing and Brown, 1979). In addition, the American Anthropological Association incorporated a human nutrition interest group in 1974 called the Council on Nutritional Anthropology, and since 2004 is known as the Society for the Anthropology of Food and Nutrition (American Anthropological Association, 2006). Historically, reductionism as an interpretive framework was discussed by David Hume $(1748 / 1955)$ in the mid-18th century, concretely formulated in economics in the early-tomiddle 19th century by John Stuart Mill (Persky, 1995), formed the core of Max Weber's methodology in sociology in the mid-20th century (Zouboulakis, 2001), and it has become synonymous with Homo economicus, or Primitive Economic Man, in microeconomics ever since (e.g., Pearson, 2000).

A reductionistic framework in anthropology and archaeology that hypothesized that the capture of energy was the key to understanding human development may have been first formulated in a comprehensive way by Leslie White in the early $20^{\text {th }}$ century (Adams, 1978). Beginning in the late 1930s, White began to outline his ideas regarding the relationships between cultural systems and technology in reference to the efficiency of energy capture ideas that he borrowed extensively from researchers such as Hermann Helmholz, Wilhelm Ostwald, and Alfred Lotka. As Binford (1972) reiterated, White's central theses were twofold: (1) that energy flow in nonliving systems fundamentally differed from that seen in the living world; in the case of the former, the second Law of Thermodynamics held that matter and energy flowed from a state of greater organization to less organized states; in the case of the latter, matter and energy flowed in the opposite direction from states of less to greater organization; and (2) as a result, those organisms that could capture and utilize free energy more efficiently than others must necessarily hold a selective advantage over others. 
The development of technology in cultural systems was all about the efficient capture of free energy:

The struggle for existence and survival has two aspects: (1) the adjustment of the organism to its habitat in terms of temperature, humidity, radiation, subsistence, etc.; and (2) the struggle with other living beings for subsistence and favorable habitats. In this struggle, in both its aspects, "the advantage must go to those organisms whose energy-capturing devices are most efficient." Any gains won are kept. The tendency of the life process is always to achieve a maximum of matter-and-energy transformation. This is true regardless of whether the energy is expended quantitatively in mere reproduction of numbers of organisms or in the development of higher forms of living systems (White, 1959:37-38).

In the passage above, White was quoting Alfred Lotka (1945), who was in fact paraphrasing his own words written 24 years prior:

Furthermore, in the competition which takes place among organisms, the advantage must go to those whose energy-capturing devices are most effective in directing available energy into such channels as are favorable to the preservation of the species (Lotka, 1921:195).

Are these reductionistic conclusions that hypothesize that energy optimization is the key to understanding the evolutionary trajectories of living organisms accurate? Is it the case, then, that human foragers would choose which foods to eat and which to ignore based on caloric return rates available to them in space and time because this subsistence strategy always offers reproductive advantages under any social and environmental circumstances? Has selection been so pervasive in molding human behavior that all economic activities can be reduced to the role they play in energy capture and reproductive fitness? Can archaeologists ignore micronutrients, or non-energy producing substances because they are meaningless to understanding human evolution? Between 1960 and the end of the 20 th century, many biologists were arguing that nonhuman animals were energy maximizers as well, (e.g., Kamil et al., 1987; Keene, 1983), so there seemed to be an emerging recognition of a foraging pattern that cross-cut the entire Animal Kingdom, explaining the foraging habits of animals as diverse as locusts, goldfish, flying squirrels, and humans (Foley, 1985).

Does empirical research confirm the validity of this all-encompassing foraging framework? A review of the biological and anthropological literature suggests that it does not (Campbell, 1987; Emlen and Emlen, 1975; Gray, 1987; Heider, 1976; Ingold, 2000; Keene, 1983; Pierce and Ollason, 1987; Schluter, 1981; Weiss, 2000). Yet the 21 ${ }^{\text {st }}$ century began where the $20^{\text {th }}$ century left off, with anthropologists and archaeologists continuing to argue that human behaviors are best explained through reductionistic models of efficiency of energy capture (e.g., Broughton et al., 2011; Winterhalder and Smith, 2000). Further, human behaviors that were shown to exist outside of an energy optimization model were argued to represent 'ancillary variables' to understanding why, for example, humans forage for food in specific ways (Winterhalder and Smith, 2000). It is more than coincidental that rather than using the phrase 'ancillary variables', John Stuart Mill (1836) called human behaviors that did not lead to an optimization of economic wealth in Capitalistic societies 'disturbing causes' 170 years ago. 
To the contrary, it has been well established that humans choose which foods to eat and which to ignore based on a multitude of factors, each of which may have dramatic effects upon mortality and fertility rates. These factors include, but are not limited to, the physiological necessity of consuming macro- and micronutrients to sustain life, taste preferences, availability of specific foods due to factors such as climate, ecological conditions in space/time and competition with other groups, social and cognitive events/festivals/feasts, food taboos related to religious beliefs, established trade networks, and technological innovations (e.g., Counihan, 1999; Harris and Ross, 1987; Thrupp, 1867). None of these variables are necessarily ancillary to explaining human behaviors; to argue that they must be because they do not lead to energy maximization reduces scientific methodology to a tautological argument.

\section{The development of nutritional ecology in anthropology}

Thirty years ago anthropology and archaeology were poised to develop a theoretical framework of human nutritional ecology. A wealth of nutritional studies in human foraging societies had already accumulated throughout the $20^{\text {th }}$ century; by the mid-1970s general anthropology texts concerning human nutritional ecology began to appear (e.g., Little and Morren, 1976). Nutritional anthropologists were noting aspects of unique human cognition and subsequent dietary choices that dramatically effected mortality trends.

The difficulties of identifying causative factors and the complex interactions of influential variables underlying even severe forms of neurological pathology may be illustrated in a review of the epidemiology of kuru, a degenerative disorder of the central nervous system found only among the Fore people of New Guinea and their immediate neighbors. The clinical features of this disease, which killed over 2,000 people between 1957 and 1973, have been fully described ... Death usually occurs within six to twelve months after the initial appearance of recognizable symptoms of the disease. Until quite recently, the disease principally affected adult females, but children of both sexes seemed equally susceptible. A genetic model was proposed which suggested that kuru was expressed in the phenotype of homozygous or heterozygous children of both sexes and in the homozygous or heterozygous adult female, but occurred only rarely in the heterozygous adult male. Within the last decade, however, the incidence of kuru has declined drastically among the Fore, more noticeably among women and children than adults. The implications of these changes led to more intensive investigations which eventually resulted in the identification of a slow-acting virus as the causative agent of the disease and the detection of ritual cannibalism as the means of natural transmission of the virus. Since women and children are the most active participants in such feasts, the gradual disappearance of ritual cannibalism among the Fore since 1957 has reduced their exposure to contamination from the highly infectious brain tissue of deceased kuru victims and altered the patterns of incidence of the disease (Underwood, 1975:28-29).

Here was an empirical link between the complex relationships amongst diet, human cognitive choice about what to eat and who within a given society is expected to eat it, and mortality trends. Despite studies such as these, holistically-based nutritional ecology studies were never embraced by archaeologists. Instead, archaeologists turned to biological studies of nonhuman animal behavior (e,g, Emlen, 1966; McArthur and Pianka, 1966; Schoener, 
1987) for models to interpret ancient human foraging decisions within an exclusively Darwinian framework. These models consisted of variations on reductionistic, energy optimization models (e.g., prey choice and patch choice models) - which I will refer throughout the remainder of this essay as the development of a Primitive Economic Man framework, or simply PEM.

PEM is a deductively-based interpretive framework that creates a narrow vision of human action centered around the maximization of a 'currency'. The currency tracked through time ranges from capital wealth to calories to babies. In archaeology, one or more currencies are often linked, such that, for example, a maximization of caloric intake relative to work effort serves to foster the successful procreation of more babies in those individuals who act accordingly.

PEM has much in common with the Homo economicus character much written about in economics for more than a century. Doucouliagos (1994:877) summarized Homo economicus thusly: 'The neoclassical economists' Homo Economicus has several characteristics, the most important of which are (1) maximizing (optimizing) behavior; (2) the cognitive ability to exercise rational choice; and (3) individualistic behavior and independent tastes and preferences.'

Some of PEM's characteristics, such as individual self-interest, can be traced back to Antiquity, while others have much in common with John Stuart Mill's (1836) theoretical construct of the model Capitalist. 'Economic man', later referred to as Homo oeconomicus, was a term applied to Mill's method of economic analysis, but his Linnaean classification was originally created in a context that was not intended as a compliment (Persky, 1995:222). According to Persky (1995), John Kells Ingram's A History of Political Economy (1888) may have been the first to use the term 'economic man' in reference to Mill's work. Persky (1995) also argues that Mill's 'economic man' was inherently Lamarkian in character, namely that one generation of rational decision-makers would pass this behavioral tendency on to the next generation, who would then embrace the Capitalistic principles taught to them, and then pass these on to the next generation, and so on. Max Weber (1915/1946) later referred to Mill's 'economic man' as Homo oeconomicus, and the term has been commonly used throughout the 20th and 21st centuries in economics.

Archaeology's reliance on PEM as a model to interpret ancient human foraging strategies is most paradoxical when one considers that the nutrition sciences, which is the discipline that has pursued links between dietary intake and maternal and infant mortality rates, has not seriously applied a similar model in their discipline since the 1920s. The nutrition sciences first began breaking away from PEM in the 19th century (Carpenter, 2003a; Carpenter et al., 1997). Carpenter et al. (1997:1018S) note that the discovery that organic and inorganic micronutrients were as essential to human development, growth, and maintenance as were the energy providing macronutrients finally broke the dogmatic thinking that protein, in particular, was of paramount importance to human health, and that reductionistic models that focused only on macronutrients could serve as a primary explanatory framework in the nutrition sciences.

While researching the historical context of ideas related to human nutritional ecology, I discovered that the early history of nutrition and the early history of PEM mirrored one another. Both stem from a number of hypothetical and philosophical beliefs about the 
universe in general, and more specifically about the place of humankind and human societies within that universe - as well as the factors that cause human societies to change, grow, and die. Many of these beliefs date back to the early 18th century, and some of them date back to the European Middle Ages and, earlier still, to ancient Greece and Rome. And some of these lingering beliefs are still maintained within modern models of PEM (Stoczkowski, 2002). Importantly, however, other disciplines such as nutrition science that once promoted ideas commensurate with PEM have abandoned these beliefs because of intensive empirical research that falsified them. The time has come for more researchers in archaeology to challenge reductionistic energy imperative frameworks, and pay more attention to the nutrition sciences by incorporating the implications of nutrition-based studies into model-building. An historical development of the ideas that led to the creation of both PEM and human nutritional ecology is a necessary step in that process.

\section{A brief historical narrative of nutritional ecology and Primitive Economic Man}

The following narrative tracks the development of ideas that characterize human nutritional ecology and the PEM frameworks, and the philosophers and scientists who played critical roles in their respective developments. For those already familiar to some degree with the literature, it will be understood that a detailed account that focused only on the philosophical belief that human nature is rooted in self-interested behaviors could fill a small library. This brief summary cannot account for all researchers who contributed in one way or another to the development of PEM and nutritional ecology. I have attempted, therefore, to choose specific authors and their works as representative of broad time periods of human thought as they relate to the development of PEM and nutritional ecology. Consider this as a place to begin an epistemological journey.

\subsection{Antiquity: The early beginnings of ideal types, optimal states of nature, self- interest, and cultural ecology}

Lovejoy and Boas (1935) and Boas (1948) summarized many of the ideas related to "primitivism" in Antiquity. Important philosophers of this early period included Lucretius (99-55 BC). A Roman poet and author, Lucretius wrote of individualism and the fact that earlier humans must have lived principally with their own welfare in mind. Self-interest was a consequence of primitive peoples living alone, each fending for his or her own needs and safety (Lovejoy and Boas, 1935:227-228). Origen (AD 185 - 254) linked rationalism with 'primitive' peoples by way of necessity. Humans are rational because God endowed us to invent better ways of behaving, which we are always striving to do, including better ways to procure food (Boas, 1948:194). On the diet of earlier peoples, the Roman priest Novatian (AD 200 - 258) noted a common conception of the time: the superiority of meat-eating (Boas, 1948:26); in contrast, Saint Basil ( $A D 329$ - 379) noted that a vegetarian fare may suffice (Boas, 1948:114). And Saint Jerome (ca. AD $331-420$ ) offered an early glimpse of cultural ecology when he wrote: "But who does not know that each people is accustomed to eat, not according to a universal law of nature, but according to what things are found abundantly in their habitat" (quoted in Boas, 1948:130-131).

Two of the most significant ideas that developed out of Antiquity included the notions of an optimal state of nature and ideal types. Saint Augustine ( $A D 354-430)$, like so many 
writers before and after him, described the first ideal-type, or optimal state of nature: Paradise, or the Garden of Eden:

Man lived in Paradise as he wished, so long as he wished what God had commanded. He lived in the enjoyment of God, from Whose goodness he was good. He lived in need of nothing, having it in his power always so to live. He had food lest he be hungry, drink lest he be thirsty, the tree of life lest old age wear him away. No corruption was in his body nor did he feel arising from his body any threats to the acuity of any of his senses. No inner disease was to be feared, no blow from without. The soundest health was in his flesh, in his spirit complete tranquility (quoted in Boas, 1948:48-49).

The Garden of Eden represented an ideal, perfect state of nature that supplied maximum subsistence and mental efficiency. After the Fall, it was each individual's choice to try and reach this optimal state as best he or she could. In this framework, rationality was defined by an optimization of behaviors (lack of greed and lust, etc.) that would then be rewarded with eternal life. The general structure of optimization amongst both the story of the Garden of Eden and the Fall of Man, on the one hand, and the natural philosophy of PEM, on the other, is remarkably similar. As unpleasant as many scientists might find this comparison, the similarities amongst the overall structure of the respective models are too complimentary to ignore.

In any case, speculations about early human behavior, as well as the creation of optimal states of nature and ideal types by philosophers of the Antiquity period hinted at the PEM framework that was to formally develop in the $18^{\text {th }}$ and $19^{\text {th }}$ centuries.

\subsection{Seventeenth and eighteenth centuries: The beast-machine, least action, the conservation of energy, and hints of a modern nutrition science}

The story of PEM changes little through the Middle Ages. The great philosophers and mathematicians of the 17th and early 18th centuries, however, would set the stage for different and often conflicting conceptions of PEM.

PEM models through the $17^{\text {th }}$ and $18^{\text {th }}$ centuries often interpreted human behavior as analogous to energy-maximizing machines. This mechanistic vision of the living universe formed an important part of the philosophy of Renee Decartes (1596 - 1650) (Brown, 1936), although the idea of pondering the question 'are animals soul-bearing beings or simply machines?' did not originate with him, and can be traced to Antiquity (Cohen, 1936:56). During the first one-half of the 17th century, however, Decartes offered a rather comprehensive vision on the nature of nonhuman animal behavior and motion by contrasting it with the human condition. This vision, referred to as animal automatism, argued that animals did not have souls or think, and therefore their behaviors could be reduced to analogies with the movements of machines - the so-called 'beast-machine' (e.g., Cohen, 1936).

Thomas Hobbes (1588 - 1679) offered two important suggestions about early human behavior in the middle of the 17th century: (1) humans were inherently self-serving beings, and (2) this self-interested nepotism naturally lead to a state of competition amongst individuals. These concepts would later become important centerpieces of Darwinian selection, as well as the nature of PEM. Hobbes called this perpetual competition amongst 
individuals a 'state of war'. Hobbes' (1651:84) famous essay leads directly to one of the most often quoted passages about early humans, which comes at the end of the following paragraph:

Whatsoever therefore is consequent to a time of war, where every man is enemy to every man; the same is consequent to the time, wherein men live without other security, than what their own strength, and their own invention shall furnish them withal... and which is worst of all, continual fear, and danger of violent death; and the life of man, solitary, poor, nasty, brutish, and short.

Hobbes established this state of early humanity to advocate a centralized authority to govern society, because it is only through the rule of law as established by governments or ruling classes that this perpetual 'state of war' could be avoided, which would then lead to greater advancements in the arts and sciences.

An important 17th century figure for the later development of the principles of least action, as well as those related to maxima and minima in nature that would develop in the 18th century was Pierre de Fermat $(1601$ - 1665). In the mid-1600s, de Fermat studied the paths of light rays. In 1657, he published what he proposed as the Principle of Least Time to describe the pathways of light, and defined the principle as 'Nature always acts by the shortest course' (Jourdain, 1913:48).

Isaac Newton (1642 - 1727) later published his Principia, or The Mathematical Principles of Natural Philosophy in 1687. In the latter 17th century, as well as the 18th and 19th centuries, Newtonian physics would be used by others to argue that the living universe could be explained via analogy to the mechanical properties of the nonliving universe. As Carpenter (1994:5) noted, some prominent medical researchers of the latter 17th century began their textbooks with overviews of Newton's Principia as a guide to understanding the human body. These analogies, including de Fermat's principle of the conservation of time in the movement of light through space, would form integral components to PEM frameworks into the early 20th century.

There also were late 17 th century experiments related to optimal states and ideal types. For example, Sloane (1699) discusses experiments designed to perfect plants through selective breeding. He relates these studies to the fact that the Creator made living things changeable in order for humanity, through selective breeding, to create ideal or perfect types for our benefit. And early in the 18th century, discussions that harkened to the times of Antiquity once again ensued regarding whether humans were or were not, by nature, flesh-eaters. For example, Wallis (1701:775) wrote that it was Man's natural state to be carnivorous.

David Hume (1711 - 1776) argued that there are uniformities of human nature, and one component of scientific and philosophical inquiries is to isolate them. Hume suggested reducing actions to smaller, more manageable components or 'regularities'. Hume also asked that even if there are regularities in human nature - which may turn out to be a principle cause of human action - does that mean that we can, by inference, predict the effect, or the outcome of those actions? Perhaps we can in mathematics, but in moral philosophy Hume answers in the negative, although this does not in and of itself render the elucidation of regularities of human behavior insignificant (Hume, 1748:95). Hume's idea that diversity of human action may be reduced to a smaller number of 'regularities' would be brought forward into Adam Smith's analysis of Capitalist markets, the latter published in 
the same year of Hume's death. It would also form the core of John Stuart Mill's 'economic man' concept in the early 19th century.

In the 18th century the Hobbesian ideals of self-interested behaviors once again took center stage as one of the principal regularities guiding human nature through the philosophical writings of Jean-Jacques Rousseau (1712 - 1778). As noted by Ogden (1940), John Locke's (1632 - 1704) Two Treatises of Government, published in 1690, argued that men have the right to do whatever they wished as long as their behaviors did not impede others from doing the same. While Locke argued that this was part of 'human nature', he did not advance the idea that such behaviors would only be represented in so-called primitive groups - it was part of all human nature. Rousseau (1755), on the other hand, argued in his Second Discourse that humans were not only self-interested beings, but that this behavior was representative of an earlier, primitive state of human nature (Ogden, 1940). Rousseau (1762:50) argued in his Social Contract seven years later, however, that self-interested preservation extended from this earlier condition into civilized society as well. Rousseau's argument was soundly attacked in England, ironically by those advocating an optimal state framework (Ogden, 1940). For his detractors, humankind's primary state of being was intellectual; what separated the civilized from the primitive was a continuous desire to reach an optimal state of perfection of being, which would lead to the greatest happiness.

Of greater significance, however, for the creation of a more modern PEM interpretive framework was the discovery of the Principle of Least Action in physics, generally attributed to Pierre-Louis Moreau de Maupertuis (1698 - 1759), and related ideas regarding the conservation of energy. The Principle of Least Action in the nonliving would later be transformed into a Principle of Least Effort in the living, with the latter serving as the living equivalent to the conservation of energy in the nonliving world. For his part, Maupertuis saw the Principle of Least Action as part of the Intelligent Design of the Divine Universe. Others, of course, interpreted the conservation of the life force differently. Maupertuis figured prominently in the debate between materialist and divine causation in the mid1700s. And although Maupertuis chose divine causation, he would provide to the materialists of the 20th century a non-divine final cause of the universe - the Principle of Least Action.

Following Maupertuis' writings on Least Action was Leonhard Euler (1707 -1783). In 1753 Euler deduced a mathematical principle of least effort based on a body that begins at rest and moves to a fixed point, the sum of all the efforts operating equal to a maximum and a minimum (Jourdain, 1913:29). Others also advanced mathematical formulae for describing the principle of maxima and minima in nature during the latter one-half of the 18th century. Included among them was Joseph Lagrange (1736 - 1813), who, in 1759, stated that it was 'his intention of deriving the whole of mechanics, by means of the principle of the least quantity of action, from a method he had of investigating the maxima and minima of indefinite integral formulae' (Jourdain, 1913:51). These principles related to least-action, least-effort, and maxima and minima in nature were later combined with hypotheses about ideal types and optimal states in nature to form the core of PEM interpretive frameworks. For example, the original principle developed in physics of maxima (PEM = greatest energetic efficiency and/or reproductive success) and that of minima (PEM $=$ with the least expenditure of energy or effort) form critical components to models derived from optimization interpretive frameworks of the $20^{\text {th }}$ and $21^{\text {st }}$ centuries. 
Early 18th century physics also helped set the stage for what was to develop in economics in the second one-half of that century. Within the throes of the development and controversy surrounding the Principle of Least Action and the conservation of the active force (energy) came the economist Adam Smith (1723 - 1790). His best-known work, Wealth of Nations, published in 1776, was one of only two major works he published in his lifetime (Nieli, 1986). Wealth of Nations became, and continues to serve as a sounding board for Capitalist principles. Within this work is also found many of the salient features of the modern PEM interpretive framework. These features include: (1) the belief that humans are, by nature, self-serving beings; (2) those that act only in their own self-interest will have a competitive advantage over those who help others; and (3) self-serving individuals naturally attempt to optimize, or to accumulate material wealth in the most efficient manner possible. These actions define rational behavior. For Smith, those who are the most efficient at the accumulation of wealth will have a competitive advantage. Importantly, if all self-serving individuals attempted to optimize their accumulation of wealth, a net benefit would be realized amongst both the individual and the society:

Every individual is continually exerting himself to find out the most advantageous employment for whatever capital he can command. It is his own advantage, indeed, and not that of the society, which he has in view. But the study of his own advantage naturally, or rather necessarily leads him to prefer that employment which is most advantageous to the society (Smith, 1776:333).

This would lead to Smith's famous line concerning the unwitting natural state of affairs that lead humans to be judged by an 'invisible hand', a process that leads to greater efficiency for both the individual and society (Smith, 1776:335):

He generally, indeed, neither intends to promote the public interest, nor knows how much he is promoting it. By preferring the support of domestic to that of foreign industry, he intends only his own security; and by directing that industry in such a manner as its produce may be of the greatest value, he intends only his own gain, and he is in this, as in many other cases, led by an invisible hand to promote an end which was no part of his intention. Nor is it always the worse for the society that was no part of it. By pursuing his own interest he frequently promotes that of the society more effectually than when he really intends to promote it. I have never known much good done by those who affected to trade for the public good.

Smith essentially defined the salient features of Homo economicus, who would be further refined into a reductionistic method of economic study 60 years later through the writings of John Stuart Mill and others. There has been much recent revisionist literature in economics concerning the role of empathy and individualism in Smith's writings (e.g., Alvey, 2004; Hill, 2004; Lamb, 1974; Nieli, 1986; Peart and Levy, 2004; Prieto, 2004; Waterman, 2002), none of which negates the central role that individualism was perceived to play in his vision of the ideal Capitalistic market operating within an optimally functioning society.

Even before Maupertuis and Adam Smith, chemistry was slowly molding itself into a respectable discipline during the 18th century. Researchers such as Robert Boyle (1627 1691) and Peter Shaw ( 1693 - 1763) were quietly setting the framework for the Chemical Revolution that would occur late in the century, which itself marks the beginning of a scientific study of human nutrition (Carpenter, 2003a). For example, in 1723 Shaw was 
'maintaining that no disease should be regarded as incurable and that there was room for the application of the Newtonian method in medicine, as well as in those sciences based on mathematics' (Gibbs, 1951:213). In 1725, Shaw also published an abridged version of Boyle's works, including footnotes that updated Boyle's original conclusions with current information, and this book was widely used between 1725 and 1817 (Gibbs, 1951). The latter part of the 18th century then witnessed the maturity of chemistry and nutrition. One of the principle players in these studies in France was Antoine Lavoisier (1743 - 1794) (Carpenter et al., 1997). But a scientific study of human nutrition was also to incur major setbacks in the very place in which it was maturing (Carpenter, 2003a:638). As Carpenter (2003a) details, the Chemical Revolution in France at the end of the 18th century witnessed the identification of the major elements of the universe, which encouraged the development of new methods in chemistry and nutrition. Being at the forefront of these studies and associating himself with the 'wrong' crowd during the Reign of Terror, however, Lavoisier was guillotined in 1794 (Grey, 1982; Hartog, 1941).

\subsection{Nineteenth century: Reductionism and an energy imperative paradigm sweep the natural sciences}

Chemistry and related nutrition studies both matured rapidly during the 19th century. In the early part of the century, François Magendie (1783 - 1855) reported on several important studies involving the nutritional requirements of mammals. Carpenter (2003a:639) recently recounted Magendie's experiment in which he fed a dog a purified diet of sugar. The animal appeared to do well for about two weeks, but one month after the experiment began the dog died. Magendie concluded that 'diversity and multiplicity of aliments is an important rule of hygiene; which is, moreover, indicated to us by our instincts' (quoted in Carpenter, 2003a:639).

Definitions of the term 'nutrition' in the early 19th century were general in nature, such as that offered by the Boston physician George Hayward in 1834: 'The process by which the body increases in size, and the waste of its organs is repaired, is called nutrition' (quoted in The North American Review, 1834:404). Nevertheless, the first one-half of the 19th century was dominated by thoughts of energy, and in particular protein, rather than nutrient diversity per se. And for these researchers, it was clear that the processes of body growth and organ repair could be explained by a balanced intake of protein. Justus Von Liebig (1803 - 1873) published his influential Animal Chemistry or Organic Chemistry in its Application to Physiology and Pathology in Germany in 1842. Liebig's argument was that muscle contractions were caused by the explosive breakdown of protein molecules, and hence protein was the only true nutrient humans required for fuel and maintenance of healthy bodies (Carpenter, 2003a:641). As Carpenter (2003a:641) noted, some of the preeminent European professors of medicine were concluding that outbreaks of ailments such as scurvy must have been caused by inadequate intakes of protein, despite overwhelming evidence that unknown nutrients found in fruits and some animal organs were known cures for these conditions. The energy imperative paradigm of the time led many researchers to ignore evidence that did not conform to the protein model - including Liebig himself.

Liebig (1842:75) clearly had an energy-imperative paradigm and the principle of maxima and minima in mind when formulating his nutrition model, which included thoughts of the efficient use of energy in all walks of life, including early human behavior: 
Cultivation is the economy of force. Science teaches us the simplest means of obtaining the greatest effect with the smallest expenditure of power, and with given means to produce a maximum force. The unprofitable exertion of power, the waste of force in agriculture, in other branches of industry, in science, or in social economy, is characteristic of the savage state, or the want of cultivation.

This energy-imperative model of human nutrition dominated the thoughts and teachings of many prominent researchers and medical professionals throughout the19th century. In this model, health and disease patterns were caused by inadequate energy intake or imbalance. As Carpenter (1994) notes, Liebig's monumental study deeply affected nutritional studies on both sides of the Atlantic until the end of the 19th century.

Not all, however, embraced Liebig's research. In fact, The North American Review for October, 1842, soundly and sarcastically attacked Liebig's conclusions.

The previous reputation of the author, as a zealous and able analytical chemist, appears to have excited very high expectations of the value of the work that he was to produce, and to have prepared the way for the enthusiastic reception it met with. Professor Gregory declared, in the British Association, as we are informed in the Preface to the American Edition, "that the Association had just reason to be proud of such a work, as originating in their recommendation;" and Professors Lindley, Daubeny, and others, concur in regarding the date of its publication "as the commencement of a new era in the art of agriculture." One of the Copely medals, of the Royal Society of London, was presented to the author the same year. The President, the Marquis of Northampton, in presenting the medal to Professor Liebig's representative on the occasion, said, "My principle difficulty, in the present exercise of this the most agreeable part of my official duty, is to know, whether to consider $\mathrm{M}$. Liebig's inquiries as most important in a chemical or a physiological light." If his Lordship will honor our Review with a careful perusal, we think he may be relieved of a part of his difficulty.

This second Report is announced with the same flourish of trumpets. The American editor declares the author to be, without question, the first living authority in Organic Chemistry; and the translator, Dr. Gregory, has "experienced the highest admiration of the profound sagacity, which enabled the author to erect so beautiful a structure on the foundation of facts, which others had allowed to remain for so long a time utterly useless", and regards its appearance as "the commencement of a new era in physiology." We have thus, already, two new eras, a new era in agriculture, and a new era in physiology; and some two years hence, when the third Report shall be forthcoming, we shall doubtless have a new era in the art of dieting and cookery.

Professor Liebig himself participates in the complacency with which his works are regarded by his admirers. His opinions are often given with a confidence which savours, not a little, of dogmatism; and he is not, always careful to mention the attainments and labors of others with all the respect, that may reasonably be demanded from a candid searcher after true knowledge. For example, he repeatedly speaks of "pretended experiments" and "experiments that teach nothing", for no other reason, that is exhibited, than that they were not favorable to his conclusions; and this, too, while his own observations are referred to only by their results, without 
any details to enable the reader to judge of their accuracy or sufficiency. He demands a confidence from his readers, which he is not willing to render to others. He enters, apparently for the first time, into the field of physiology, with a feeling nearly allied to contempt for the attainments of all its previous cultivators (The North American Review 1842:464-466).

Another important nutritional line of work which would be brought forward from the 1600 s into the 19th century involved studies of the human body as analogous to an engine, with an interest in calculating the efficiency of that human engine. In 1861, for example, Hermann Helmholz (1821 - 1894) "estimated that the human 'engine functioned with about 25\% efficiency"' (quoted in Carpenter, 2003a:642). In another related experiment, a Swiss scientist compared the amount of protein that a human body could break down with the amount of energy expended by a pair of mountain climbers, and concluded that the fuel utilized by the human body must come primarily from fats and carbohydrates, not from the breakdown of protein (Carpenter, 2003a:642), an interpretation upheld by later studies.

The latter part of the 19th century, however, saw a continued focus on protein and energy as the primary sources of nutrition leading to healthy humans. Wolf and Carpenter (1997:1255) noted that, between about 1860 - 1910, Germany attracted many American and European postgraduate students who desired to learn from the most influential nutritional minds of the day. Two important figures that would carry the energy cause late into the century were Carl Voit (1831 - 1908) in Germany and Wilbur Atwater (1844 - 1907) in the United States. Nevertheless, according to Atwater (1888:257-258), although the energy producing nutrients were most important, a variety of foods were required to consume the necessary diversity of energy types needed to efficiently run the human mental and physical machine.

An important economic researcher of the 19th century who advocated an ideal-type analytical framework was John Stuart Mill (1806 - 1873). Mill, and later Max Weber in sociology, both utilized a deductively-based scientific method of investigation that relied on reductionistic frameworks of ideal types. Zouboulakis (2001) recently analyzed both Mill's and Weber's views on individualism, ideal-types (optimization), methodological reductionism, and the Capitalistic tendencies of human nature. Zouboulakis (2001:32) noted that Mill's method of economic analysis (dubbed the study of 'economic man' by later writers) was an attempt to isolate behaviors within Capitalistic markets that specifically addressed an actor's 'desire for wealth'. Mill (1836) recognized that motives other than the desire for wealth were also in operation in Capitalistic markets, and these behaviors he called 'disturbing causes'. Furthermore, these disturbing causes eventually must be taken into consideration in explaining the full suite of human motives. Nevertheless, Mill believed that a focus on the desire for wealth would explain much of the essential actions driving behaviors in Capitalist markets (Zouboulakis 2001).

The latter-half of the 19th century also saw the maturation of the discipline of anthropology. Edward Burnett Tylor (1832 - 1917), considered by some the 'father' of modern anthropology (e.g., Radin 1970) published his classic work Primitive Culture in 1871. Tylor grappled with the notion that the laws of the inorganic world, as well as those formulated in the study of nonhuman plants and animals, could be equally applied to human behavior. Thus, Tylor (1871:2) questioned the validity of studying human action as just another example of nature's overarching laws: 
Our modern investigators in the sciences of inorganic nature are foremost to recognize, both within and without their special fields of work, the unity of nature, the fixity of its laws, the definite sequence of cause and effect through which every fact depends on what has gone before it, and acts upon what is to come after it... But when we come to talk of the higher processes of human feeling and action, of thought and language, knowledge and art, a change appears in the prevalent tone of opinion. The world at large is scarcely prepared to accept the general study of human life as a branch of natural science, and to carry out, in a large sense, the poet's injunction to 'Account for moral as for natural things.' To many educated minds there seems something presumptuous and repulsive in the view that the history of mankind is part and parcel of the history of nature, that our thoughts, wills, and actions accord with laws as definite as those which govern the motion of waves, the combination of acids and bases, and the growth of plants and animals.

But Tylor (1871:3) sees justification in this very assumption, and thus anthropology is born with the goals of establishing laws of human action that accord with those of the inorganic and nonhuman worlds:

We may hasten to escape from the regions of transcendental philosophy and theology, to start on a more hopeful journey over more practicable ground. None will deny that, as each man knows by the evidence of his own consciousness, definite and natural cause does, to a great extent, determine human action. Then, keeping aside from considerations of extra-natural interference and causeless spontaneity, let us take this admitted existence of natural cause and effect as our standing-ground, and travel on it so far as it will bear us. It is on this same basis that physical science pursues, with everincreasing success, its quest of laws of nature.

Tylor therefore advocates the same deductive approach as that discussed by Mill. What, then, should constitute the reductionistic hypothesis through which human action, past and present, can be interpreted? Tylor (1871:6) responds that it is the self-evident truth that all of humankind can be classified as savage, barbaric, or civilized. Further, these self-evident truths are to be considered universal and timeless, applicable to all peoples, in all times, at all places.

Mid-to-late 19th century racism disguised as sound science relied on the same general principles of ideal-types, optimal states, and reductionism to create visions of superior and inferior human races. The ideal race was set in parts of Europe, and its salient features were identified, often by measurements of the mouth region and the skull cap. The general methodology was similar to the creation of the perfect 'economic man' operating within Capitalist markets - only here the issue was the perfection of the physiological, mental, and social characteristics amongst humans. Thus, with ideal type/optimal state methodology in hand, these authors set about a scientific treatise on the idealness of human races by defining their salient features and then judging them against a conjectural optimal state that humanity could strive to become. In this context, race was the currency to track historically, while human perfection served as the optimal state. Policy adoption by governments served as the goal of 'social selection' to reach the optimal state of humanity.

Some of the earliest studies of cranial measurements were completed entirely for medical purposes, and had no racial undertones (e.g., Friend, 1699). Interestingly, one of the earliest 
works with racial implications focused not on measurements of the brain case, but on measurements of the mouth. Alexander Nasmyth (1758-1840) argued that the lack of tools, lack of cooking meats, and the prolonged suckling of infants in primitive races caused them to become more prognathic in the mouth than the civilized races, who used tools more often than the mouth in processing foods. The measurement of the mouth was a direct reflection of the degree to which a society was living in an optimal state of humanity - with upright jaw structure representing the ideal type of mouth. It was out of this perfect mouth type that prognathism developed in the degenerate savages who migrated from north to south long ago (Nasmyth, 1848:193-194).

Late in the 19th century, the principles of ideal racial types and an optimal state of humanity based on racial purity took a cruel turn for the worst (e.g., Gould, 1981). In the United States, Carlos Closson was one of its leading proponents. Closson attributed the rise of the 'great' civilizations to the ambition of the pure races; their decline was instigated by cross-breeding with the irrational races, including the Fall of the Roman Empire (Closson, 1896:460-461). Closson pondered what to do about all of this racial mixing (irrational behavior) that has been occurring for so long, driving down the idealtype of race and the optimal state of humanity. He decides there are six fixes for this problem, categorized thusly: 'military, political, religious, moral, legal and economic' (Closson, 1896:462). 'Military selection' is always an option to get rid of an inferior race, but the costs in superior men of the better races through warfare is considered too high. Besides, there are better ways to get rid of people, to mention nothing of the fact that inferior breeds may be useful to serve the elite race and to complete lowly tasks that their superiors may not wish to engage in themselves. So Closson (1896:465) offered six suggestions of how to assist 'social selection' to operate in order to "constitute a natural aristocracy among a given people". Closson (1896) attributed much of his data to the writings of Georges Vacher De Lapouge (1854 - 1936). De Lapouge, in turn, attributes the originality of the idea of a scientific study of superior and inferior races to the Count de Gobineau between 1853-1855 (De Lapouge and Closson, 1897). De Gobineau is described as a 'genius' by De Lapouge and Closson (1897:56-57).

PEM frameworks of the late $1^{\text {th }}$ century continued the Hobbesian idea that foragers were continually facing famine and a caloric-depleted death. Garrick Mallery (1831 -1894) noted that "Brutes feed. The best barbarian only eats. Only the cultured man can dine. Savages eat when they can get food and continue to eat so long as the food lasts" (Mallery, 1888:195). John Wesley Powell (1834 - 1902) provided a vision of naked Darwinian selection: "Competition among plants and animals is fierce, merciless, and deadly; out of competition fear and pain are born; out of competition come anger, and hatred, and ferocity" (Powell, 1888:301). Baker (1890:299) combined Mallery's and Powell's vision into one succinct concept: "The human body abounds in testimony of this sort - indications of the pathway by which humanity has climbed from darkness to light, from bestiality to civilization - relics of countless ages of struggle, often fierce, bloody, and pitiless". Burnett (1892:249) concurred:

It is no part of Nature's plan to be merciful; the fundamental law of all her actions is inexorableness. Pitliless and stern, with a deaf ear turned to all appeals for consideration or extenuation, she lays the icy fingers of her immutability upon the victim and exacts payment of the penalty in full. 
But late 19th century anthropology was not the only discipline guilty of such visions - some economists continued its visions of PEM, too. E. L. Godkin (1831 - 1902), for example, wrote that:

It is no less true that political economy, no matter how defined, cannot be taught without assuming the existence of an Economic Man who desires above all things, and without reference to ethical considerations, to get as much of the world's goods as he can with the least possible expenditure of effort or energy on his own part... Ethics and religion in so far as it furnishes a sanction for ethics, exist for the purpose of deflecting him from his normal course (Godkin 1891:491-492).

The same deductively-based, reductionistic methodology also led to some 'higher-order' explanations in the 19th century that, in hindsight, entered the realm of ridiculous. For example, Louis Robinson (1894) ironically began his deductively-based conclusions about past foraging behavior by arguing that they could only have been brought about by previous inductively-driven research. The inductively-generated model that Robinson gives credit is Darwin's theory of evolution:

Although the Darwinian doctrine of human descent has now been accepted for the best part of a generation, we have as yet done little in applying it in interpreting the many records of the past which are found in our bodies. The logical tactics necessarily adopted by the pioneers of the movement are to some extent accountable for subsequent slow progress. While the main question was in dispute all advocates of the evolution theory were striving to establish the principle. In doing this it was obviously necessary to use the inductive method (Robinson, 1894:467).

But now that the general principle of evolution, developed through inductively-based scholarship, has been accepted by all serious and knowledgeable scientists, it is time to jettison the inductive approach to understanding the past through this methodology - for deeper levels of understanding, we are told, we must instead turn to deduction:

But it is evident that the methods resorted to for purposes of conquest are by no means those which render a new territory of permanent value to the captors. When the fight is over and the victory won, progress is not aided by mangling the carcass slain, or by marking time on the field of battle. Now that the principles of evolution have taken their place forever among the axioms of science, we must resort to deductive tactics if we hope to enjoy the fruits of victory.

It is wonderful, when this is done, how many of the most dull and trivial facts of everyday experience become alive with interest. The new philosophy is found to possess a transmuting power which changes the very dust of the earth into golden grains of knowledge (Robinson, 1894:467).

Robinson argues that many of the common behaviors seen in human civilized babies can be traced directly back to our 'pithecoid arboreal ancestor' - these fruits become sweeter when we take the self-evident truths that our ancestors lived a nasty, brutish life, one in which foragers were ever-staring caloric-depleted death in the face - and place these truths within deductive models based on the general Darwinian evolutionary framework. The eight innate behaviors of human infants that Robinson chooses to deductively explain through the Darwinian framework are: 1) why human infants are fat; 2) why human infants enjoy 
placing objects in their mouths; 3) why human infants are cute; 4) why human infants cry loudly; 5) why human infants fear strangers; 6) why babies are afraid of the dark; 7) why human infants are terrified of ferocious beasts; and 8) why human infants are jealous. For example, the deductively-based explanation of why babies are afraid of the dark was described thusly:

A fear of being left alone in the dark is almost universal among little children, and yet, in ninety- nine cases out of a hundred it is purely instinctive and is not founded on personal experience...As I have remarked before, nature develops no new organ or quality except to meet a vital want, and has a way of adapting means to ends which does not allow of the least surplus. An organism is as exactly adjusted to its environment as a casting in metal or plaster to the mould which gave it shape.

The unreasoning night-fears of infancy may therefore be read as a record of past circumstances which at one time rendered them necessary in preserving life. When the cave bear and that grisly nondescript the saber-toothed tiger (machairodus latidens) were contemporary with the English troglodyte, and when hyenas which could crunch up the shin bone of an ox like a stick of macaroni were his next-door neighbors, it was obviously indiscreet for a defenceless human being to wander abroad after nightfall (Robinson, 1894:475-476).

More than a century after these deductively-based interpretations of the human infant in foraging societies were proposed, the dangers inherent in extreme reductionism that relies on Darwinian principles as a panacea to explain past human behavior are easily illuminated. Most of the salient characteristics of the PEM framework are embedded in Robinson's writings, including Darwinian selectionist principles as the sole interpretive framework for the explanation of human action that matters in a developmental sequence, as well as selfinterested preservation.

However, not all of the deductively-driven models of the late 19th century were similar to Robinson's. In fact, perhaps the earliest modern-looking optimal foraging model can be found not in the biological literature of the 1960s, but in late 19th century anthropology. Perhaps the earliest formal optimal foraging model in anthropology was proposed by Otis Tufton Mason (1838 - 1908) in 1894, anticipating those proposed in biology by 70 years. Mason (1894:275) begins by stating a common perception of both human nature and the life of savages as filled with hardships: "The chief contest for the inner man has been to appease the insatiable cravings of hunger and thirst". These inner and outer hardships created a tendency for humanity to stay stationary in order to procure the material items necessary to overcome them, but also an urge to migrate - to move to greener pastures in order to find comfort. According to Mason, in both of these pursuits, humans naturally chose paths of least resistance based on the principles of maxima and minima because the day-to-day struggle for life was so harsh. And here, Mason (1894:276) has also anticipated the studies of least effort in experimental psychology by at least 30 years:

The law of the circle of employments and of permanent migration may be called the maxima and minima of effort - that is, men have always bestirred themselves the year round and moved about the world on lines and to places where there seemed to be promise of the greatest bodily comfort and security for the least effort. 
In this paper especial attention will be paid to this maxima and minima in relation to the food quest, though it will be seen that following this line conducts also to the best results in the other activities mentioned.

Mason then proposes his optimal foraging model to explain the peopling of the Americas. Anticipating modern prey choice models by more than 80 years, Mason (1894:278) argues that the most attractive game within inner terrestrial-based environments is large herbivores, but where available, marine environments offer the greatest subsistence rewards for the least amount of effort: "The greatest natural food supply for the least effort, with few exceptions, was in the water". Mason proposed that humans choose which foods to eat and which to ignore based primarily on net gross food return rates, considering the abundance and variety of foods in relation to their availability on a seasonal basis, capture costs, and preparation costs. Given these principles, Mason (1894:279) proposes a deductively-based model of the probable migration route of the earliest inhabitants of North America - one that likely began in the Indo-Malaysia region of Asia, reached the Pacific coast of North America, and eventually ending in South America.

The theoretical development of PEM was essentially complete by the end of the 19th century. Therefore, there would be only minor developments in optimization models throughout the 20th century. From this point forward to the present day, optimization models have simply been applied to different data sets, often under the disguise of different names to make them appear new or unique.

\subsection{Early $20^{\text {th }}$ century: Primitive Economic Man runs his course in nutrition, becomes despised in anthropology, but lands feet-first in experimental psychology}

Max Weber (1864 - 1920) took the research methodology that focused on ideal-types and conjectural optimal states of behavior to define rationality into 20th century sociology (Zouboulakis, 2001:30). In Weber's 1915 essay concerning Indian religion, for example, he gives an account of the ideal-type method of analysis, noting that the rational behavior generated from it does not necessarily exist in reality, rather it serves as a point of reference to judge how closely actual behaviors reach the conjectural optimal state (Weber, 1915, translated in Gerth and Mills, 1946:323-324):

The constructed scheme, of course, only serves the purpose of offering an ideal typical means of orientation. It does not teach a philosophy of its own... As will readily be seen, the individual spheres of value are prepared with a rational consistency which is rarely found in reality. But they can appear thus in reality and in historically important ways, and they have... They enable us to see if, in particular traits or in their total character, the phenomena approximate one of our constructions: to determine the degree of approximation of the historical phenomenon to the theoretically constructed type.

Here, then, are all the elements of the deductive method of defining rationality in the analysis of social phenomena. Weber was one of the early users of the term 'Homo oeconomicus' to refer to Mill's model Capitalist. But "Weber ... rejected income-maximizing homo economicus and sought to replace him with the status-maximizing homo politicus, at least within the bounds of pre-modern Europe" (Christesen, 2003:31-32). Modern archaeological models have combined Weber's Homo politicus with PEM's Darwinian 
framework to form models under various names, including "costly-signaling theory", "prestige hunting", and "showing off" (e.g., Broughton and Bayham, 2002).

\subsubsection{Ideal cases and reductionism continued: The optimization prophecy of Wilhelm Ostwald}

Early 20th century textbooks on theoretical mechanics and natural philosophy continued the dialogue on the principle of maxima and minima in nature and the conservation of energy. An early 20th century textbook on theoretical mechanics by James Hopwood Jeans (1877 1946) was later cited by George Zipf as one of his inspirations for developing the Principle of Least Effort in psychology (see below). The goal of several influential natural philosophy texts remained unchanged from earlier times: unite the actions of the living and nonliving under a single principle: the efficient utilization of energy. One of these general texts was published in 1910 by Wilhelm Ostwald (1853 - 1932). As in Mill's economics and Weber's sociology, Ostwald argues for a focus on ideal-types, or optimal states, and reductionism as the best method for investigating natural philosophy and science. But Ostwald (1910:45) specifically argued that Mill's disturbing causes are irrelevant when he wrote that "...we repeatedly so find or can form our experiences that certain natural relations preponderatingly determine the experience, while the other parts that remain undetermined fall into the background. The prophecy will cover so considerable a part of the experience that we can forego previous knowledge of the rest". Ostwald (1910:46-47) then outlined what can be considered the current working deductive model used in North American archaeology today:

A case in which none of the extraneous elements of experience operate is called an ideal case, and the inference from a series of values leading to the limit-value is an extrapolation. Such extrapolations to the ideal case are a quite natural procedure in science, and a very large part of natural laws, especially, all quantitative laws, that is, such as express a relation between measurable values, have precise validity only in ideal cases.

Ostwald argues that natural philosophy should decide which finite causes are likely to be the most instrumental in guiding behaviors in the living universe. Sound science makes these reductionistic determinations, and then seeks out those actions or behaviors that appear to confirm the law. Scientists can make observations, interpret them according to the law, and this makes the living world knowable and useful. So what should the final cause of living action be?

Since our opinion as to what constitutes a higher and lower organism is doubtless arbitrary, let us ask whether it is not possible to find an objective standard by which to measure the relative perfection of the different organisms. The question must be answered in the affirmative when we take into consideration the following. Since the quantity of available free energy upon the earth is limited, the organism which transforms the energy at its disposal more completely and with the least loss into the forms of energy necessary for the function of life, must be regarded as the more perfect organism (Ostwald 1910:176).

If we substitute the concept of 'fitness' for the word 'perfect' in the passage above, we would have the essential argument of modern optimization models and current constructs of PEM under the umbrella of "evolutionary ecology". Here is Ostwald's passage again with the substitution of two words: 
Since our opinion as to what constitutes a higher and lower organism is doubtless arbitrary, let us ask whether it is not possible to find an objective standard by which to measure the relative [fitness] of the different organisms. The question must be answered in the affirmative when we take into consideration the following. Since the quantity of available free energy upon the earth is limited, the organism which transforms the energy at its disposal more completely and with the least loss into the forms of energy necessary for the function of life, must be regarded as the more [fit] organism.

Ostwald's prophecy was about to become law, despite the best efforts of nutrition science, which was about to bury PEM, and anthropology, which learned to despise him in the early $20^{\text {th }}$ century.

\subsubsection{Nutrition science begins to build Primitive Economic Man's coffin}

At the time of Ostwald's writings, a major breakthrough in the understanding of nutritional requirements of human health was occurring. In 1911, E. B. Hart of the University of Wisconsin and colleagues embarked on a program to test some of Liebig's protein/energy imperative conclusions (Harper, 1997:1027S-1028S). In what became known as the 'Wisconsin single grain experiment', Hart and colleagues definitively showed that healthy diets required more nutrients than simply protein and a few minerals (Harper, 1997:1027S1028S).

It was also becoming widely known that mice fed purified diets consisting solely of energy sources died rather quickly, but when milk was added to these diets the animals flourished. The implication of these studies was that there existed a type of nutrient, or a number of nutrients, other than proteins, carbohydrates, and fats, that were present in milk that made the difference between life and death in the living universe. One of the implications was that the living world was more than machines of energy moving through space. That analogy was untenable.

One of these important papers appeared in 1915, and was entitled The Nature of the Dietary Deficiencies of Rice (McCollum and Davis, 1915). In this paper we get a first-hand account of researchers who knew the energy-imperative paradigm to be wrong, and knew also that other, undefined organic-based nutrients had as much impact on mammalian growth and development as proteins, carbohydrates, and fats. McCollum and Davis (1915:183-184) called these undefined nutrients 'accessory substances'. The fat-soluble accessory substance that McCollum and Davis knew to be vital to mammalian growth and development would later be known as vitamin-A. The water-soluble accessory substance(s), for which McCollum and Davis were unsure of the number, could have included folate, riboflavin, and/or thiamin, all critical to human growth and body maintenance.

Thus, McCollum and Davis (1915:185) dismantled the notion that, in the living world, energy alone could promote growth when they wrote that: "...all of which make it evident that purified proteins, fats having the growth-promoting property, and salt mixtures of appropriate composition, cannot adequately supplement polished rice so as to produce a diet which will support growth". In a case of bitter irony, then, McCollum and Davis (1915:192) argued that increasing attention to the non-energy producing accessory substances would lead to significant economic benefits through better health and nutrition. 
The second decade of the 20th century finally witnessed the naming of these accessory substances - 'vitamines' (Frank and Dubin, 1920; Funk, 1925, 1926; Myers and Voegtlin, 1920). By 1918, some nutritionists were actively promoting the essentiality of these nutrients to healthy diets, and recognizing that diversity of diet was necessary to consume adequate quantities of these essential nutrients:

Vitamines as a class are now acceptably divided into a fat soluble and a water soluble type. Both are absolutely essential in a complete diet and both vary considerably in their occurrence. Individually many foods are deficient in one or both of them, but safety has undoubtedly been assured to the consumer by his desire for variety (Steenbock, 1918:119).

And by the end of the decade, three 'vitamines' were being named by letter (e.g., Dutcher et al., 1919:184). Shortly thereafter, nutritionists were on the trail of other non-caloric nutrients that were critical to the survival of animals. While not yet chemically isolated, they were learning that some foods such as green leafy vegetables were so rich in these nutrients that they could make the difference between life and death. Consider these passages from Evans and Bishop (1922:650-651), who were hot on the trail of 'substance $\mathrm{X}^{\prime}$, later called vitamin $\mathrm{E}$ :

Natural foodstuffs contain a substance, $X$, which prevents such a sterility or which cures the disorder occasioned by the purified dietary regime. We have thus been able to witness a comparatively sudden restoration of fertility to animals of proven sterility, and whose controls continued sterile, by the administration of fresh green leaves of lettuce.

These studies demonstrated, once and for all, that energy sources could not be considered by themselves a key currency to tracking animal health patterns. From this point (roughly 1920) forward to the present day, advocates of PEM models would ignore these essential facts - but in the earliest stages of the 20th century, PEM ideals were still in good company to all but a few heretics who were quietly building PEM's coffin in the nutrition sciences.

\subsubsection{Alfred Kroeber's superorganic challenge to Ostwaldian prophecy}

In an important early 20th century anthropology paper, Alfred Kroeber (1876 - 1960) challenged the ideas that Darwinian selection could explain all human behaviors of any consequence to science, as well as the notion that human action could be understood through mechanistic principles based on reductionistic ideals (Kroeber, 1917). Kroeber's prophecy, however, was that the study of human behavior would be overtaken, so to speak, by the forces of organic evolution, while the true study of the meaning of human action the social - would be swept aside in the reductionism inherent in zealous claims that the principles of Darwinian selection could explain the essence of human thought and action. Considering the tenacity of the PEM framework, Kroeber can be regarded as a seer in this regard. Kroeber's analysis, indeed criticism, of interpreting human action under the same theoretical principles as organic evolution anticipated some of the objections to optimization approaches developed much later in the century.

Kroeber $(1917: 208,212)$ argued for holistic views of human action, and warned against scientific reductionism: 
Science will attack historical material - social material - by converting it into organic terms - whether psychical or physical does not matter, so long as the ever present individual physiological aspect or basis of the social phenomena is dealt with. These organic results will then be ready for interpretation by the methods of physics and chemistry. Thus the material will be made part of that great unit, the system that justifies and elevates science to its high plane - the system that is pervaded by the principle of mechanical causality as its essence.

The forces and principles of mechanistic science can indeed analyze our civilization; but in so doing they destroy its essence, and leave us without understanding of the very thing which we seek.

\subsubsection{Bronislaw Malinowski heads to the Trobriand Islands and fails to discover Primitive Economic Man}

In the 1920's, PEM was so pervasive in the thoughts of economists and others that Bronislaw Malinowski (1884 - 1942) devoted some time to dismembering him in his classic Argonauts of the Western Pacific, first published in 1922:

Another notion which must be exploded, once and for ever, is that of the Primitive Economic Man of some current economic text books. This fanciful, dummy creature, who has been very tenacious of existence in popular and semi-popular economic literature, and whose shadow haunts even the minds of competent anthropologists, blighting their outlook with a pre-conceived idea, is an imaginary, primitive man, or savage, prompted in all his actions by a rationalistic conception of self-interest, and achieving his aims directly and with the minimum of effort. Even one well established instance should show how preposterous is this assumption that man, and especially man on a low level of culture, should be actuated by pure economic motives of enlightened self-interest. The primitive Trobriander furnishes us with just such an instance, contradicting this fallacious theory. He works prompted by motives of a highly complex, social and traditional nature, and towards aims which are certainly not directed towards the satisfaction of present wants, or to the direct achievement of utilitarian purposes. Thus, in the first place, as we have seen, work is not carried out on the principle of the least effort. On the contrary, much time and energy is spent on wholly unnecessary effort, that is, from a utilitarian point of view (Malinowski 1922:60).

Despite ethnographies such as Malinowski's Argonauts, essays by Kroeber, and research on vitamins in nutrition, these studies did nothing to slow the progression of PEM in natural philosophical texts. If anything, the PEM framework became even more trustworthy for its proponents than ever before. And nobody exemplified this fact any better during the third decade of the 20th century than Alfred Lotka.

\subsubsection{The extended hand of Wilhelm Ostwald: Alfred Lotka's energetics and human nature}

In precisely the same year that Malinowski published his Argonauts, Alfred Lotka (1880 1949) was publishing a series of articles in the Proceedings of the National Academy of Sciences advocating a mechanistic view of human evolution based on energetics. Lotka (1922:147) wrote that: 
It has been pointed out by Boltzmann that the fundamental object of contention in the life struggle, in the evolution of the organic world, is available energy. In accord with this observation is the principle that, in the struggle for existence, the advantage must go to those organisms whose energy-capturing devices are most efficient in directing available energy into channels favorable to the preservation of the species.

The first effect of natural selection thus operating upon competing species will be to give relative preponderance (in number or mass) to those most efficient in guiding available energy in the manner indicated.

Three years after these writings, Lotka (1925) published his Elements of Physical Biology. Here, Lotka detailed his ideas concerning both the mechanical side of human behavior and the other behaviors guided more by cognitive choice. Lotka (1925) called the mechanistic side of human action 'rigid behavior', or, more famously, the 'automaton type'; the more symbolic aspects of human action he called the 'elastic type'. Elastic behaviors, of course, are nothing more than Mill's (1836) 'disturbing causes' and Weber's Homo politicus.

Lotka (1925:350) then states that 'lower' organisms such as plants live on an "automaton type of behavior schedule"; "But in the higher animals, and most particularly man, we have an elastic behavior-schedule....". Ironically, Lotka (1925) then argues that elastic behaviors are superior to automaton types. Any changes, or adjustments, in the operation of free choice would naturally tend toward those behaviors favorable to the individuals of the species, and thus they would tend toward a maximum. In this case, the maximum or currency to track is energetic efficiency. But then Lotka (1925:352) considers all of these deductions within a framework of ideal types and optimal states, and in the process reduces them further to the rigid types of human action, turning his model of the ideal type of human being into an automaton, representing classic PEM modeling:

Relation between Ideal and Actual Organism. We have thus far considered an ideal type of organism of the free choice type of behavior schedule, constructed on the principle that the $\lambda^{\prime}$ s shall be so chosen as to make the proportional rate of increase $r$ a maximum.

It remains to consider the relation between this ideal type of organism and the actual organism. The actual organism is not consciously guided by any consideration of the effect of his actions upon the rate of increase of his species... What guides a human being, for example, in the selection of his activities, are his tastes, his desires, his pleasures and pains, actual or prospective. This is true, at least, of some of his actions, those which are embraced in his free-choice type of behavior schedule. That the human behavior schedule also contains an element of the non-elastic (automaton) type may be admitted in deference to those who have leveled their destructive criticism at the hedonistic account of human behavior. We may, however, restrict our discussion here to that portion or phase of conduct which is determined by hedonistic influences.

So what portions of the human condition naturally lend themselves to hedonisticallygenerated models of automaton action? It's foraging for food, because the health and welfare of plants and animals are primarily determined by the efficient capture of free energy: 
The behavior schedule has been quantitatively defined in terms of energy. This if not the only possible definition, is at any rate a convenient one, and has also the advantage of emphasizing the important relation of the organism to the energy sources of his environment. His correlating apparatus is primarily an energy capturing device - its other functions are undoubtedly secondary. The life contest, then is primarily a competition for available energy, as has been pointed out by Boltzmann. Energy in this sense and for this reason has value for the organism - which is a very different thing from saying (as some have said or implied) that economic value is a form of energy (Lotka 1925:354-355).

Lotka (1925:356-357) places the self-interested energy-maximizers into the classic Darwinian framework of the struggle for survival, thereby completing the optimality-based PEM framework:

Our reflections so far have been directed to the selfish efforts of each organism and species to divert to itself as much as possible of the stream of available energy.

This at least seems probable, that so long as there is an abundant surplus of available energy running "to waste" over the sides of the mill wheel, so to speak, so long will a marked advantage be gained by any species that may develop talents to utilize this "lost portion of the stream." Such a species will therefore, other things being equal, tend to grow in extent (numbers) and this growth will further increase the flux of energy through the system. It is to be observed that in this argument the principle of the survival of the fittest yields us information beyond that attainable by the reasoning of thermodynamics.

Lotka (1925:430-431) ends with a metaphysical idealism, with one more deductive state of optimality to propose - man's unity with Nature.

The fact seems to be that the operation of a fundamental purpose or design in Nature is one of those things that can neither be proved nor disproved. We are, therefore, at liberty, if we so choose to, believe in such a purpose. This is an occasion for the legitimate exercise of faith.

We may, if we will, embrace this purpose for our own. Such will spells ultimate survival. No better guarantee for the welfare of the race could be furnished, than its essential harmony with Nature. Selection, then, would seem to point the way toward a will in conformity with that general principle which, for want of a better term, we may describe as the Supreme Purpose of the Universe.

\subsubsection{The non-caloric organic nutrients change the face of nutrition and disease: The vitamin revolution buries Primitive Economic Man in the nutrition sciences}

Research into the 'vitamines', especially vitamins A, B, C, and E accelerated during the early 1920s (e.g., Bishop, 1922; Evans and Leersum, 1929; Funk and Dubin, 1920; Funk, 1925, 1926; Myers and Voegtlin, 1920). With increasing discussion of the value of incorporating these nutrients into diets, some were advocating caution in the creation of dietary guidelines for the intake of the non-caloric nutrients because vitamin research was being performed almost exclusively on nonhuman animals (Mitchell, 1922). For example, by 1925 vitamin E deficiency had been advanced as one of the factors that had a primary influence on sterility in mice (Evans and Burr, 1925). 
Then, between 1926-1939, in 13 short years, 12 essential vitamins had been isolated chemically, including thiamin, niacin, folate, riboflavin, and vitamins $\mathrm{B}_{6}, \mathrm{C}, \mathrm{A}, \mathrm{D}, \mathrm{E}$, and $\mathrm{K}$ (Carpenter, 2003c:3028, Table 2). As noted above, between about 1900 - 1920, a fundamental shift in thinking within nutrition science took place. Within these two decades, it became apparent that many diseases and malformations, including scurvy, rickets, beriberi, night blindness, and pellagra could be prevented or treated by adding specific food items that contained nutrients other than carbohydrates, fats, and proteins to the human diet (e.g., Elvehjem, 1949). These afflictions, which greatly influenced human demographic patterns in some regions, were not caused by viruses nor by insufficient intake of energy or minerals. Rather, they were caused by deficiencies in unknown organic-based nutrients - and the search was on to define and isolate them (Carpenter, 2003c; Carpenter et al., 1997). This brought about the revolution of understanding of essential nutrient diversity and human health and development in nutrition science between 1910 -1940. And this spelled the death of PEM modeling in that discipline.

For instance, it was discovered that 'Factor A' (later called vitamin A) was crucial to understanding growth and development in mice, as well as treating and preventing night blindness - although this vitamin was not isolated chemically until 1939 (Carpenter, 2003c). Growth and the 'antiberiberi factor' were related to 'vitamin B' (with $B_{1}$ isolated in 1926); rickets was tied to a factor we now call vitamin D, and isolated in 1931, and so forth (Carpenter, 2003c). As the vitamins began to fall to science, so to speak, the essential minerals began to receive increasing attention in the 1920s and 1930s as well. As an example, copper was isolated as a factor in the health of cattle in 1931 (Carpenter, 2003c).

One final piece of nutrition research that falls between the two decades 1920-1940 involved the relationship between energy consumption and life span. As Carpenter (2003c) notes, as early as 1917 researchers had discovered a link between early calorie restriction and increased life span in mice. In 1927, Clive McCay (1920 - 1967) confirmed this finding, concluding that the life span of rats could be greatly enhanced by restricting their consumption of calories (energy) early in life.

Between 1920 - 1940, then, the nutrition sciences firmly established the link between dietary diversity and human health patterns, including the significant roles played by non-caloric nutrients. This general principle has been confirmed by thousands of empirical research projects conducted over the past 65 years - and forms the central concept of nutritional ecology.

\subsubsection{Primitive Economic Man moves into experimental psychology}

Beginning in the 1930s, experimental psychologists decided to apply PEM modeling in their research. One of the more important articles linking animal behavior with the principle of least effort was published by Joseph Gengerelli (1905 - 2000) in 1930. Gengerelli studied the behavior of rats moving through a maze to obtain food at the end of the line. Current PEM frameworks are similar to the research Gengerelli carried out on rats in the 1930s. Substitute 'ecological habitat' for the maze and 'human foragers' for rats, and one essentially sees the basics of modern PEM modeling. Gengerelli's early research also continued the tradition of framing itself within the parameters of reductionism, ideal-types or optimal states, least effort or action, maxima and minima, and deductive reasoning. 
In the press and strife of actual research...the problem is to determine which one of the "blunt facts" we shall choose as the corner stone of our explanation. Obviously we must choose those which are capable of embracing all of the varied phenomena with which we have to deal. Also those facts which are "self- evident"; which do not themselves stand in need of explanation.

This is the crux of our problem. In psychology, at least, there is no unanimous agreement as to what the fact or facts are which do not stand in need of explanation... In general, modern psychologists have been too ambitious. They have been drawn with an inevitable fatality to the "self-evident" facts and laws of mechanics (Gengerelli 1930:194-195).

Gengerelli attempts to establish a 'law' of least action, but he notes that the law applies only to specific circumstances; namely specific external and internal conditions arising from need (1930:228-229):

In view of the fact that our ordinary tools of frequency, recency, redintegration, etc., fail to resolve the phenomenon to a simpler, more fundamental, level, there is only one thing left to do: - state the facts and their conditions as simply and as abstractly as possible. We are therefore forced to state in a somewhat axiomatic form that it is a fundamental law of behavior that the organism, under the stress of a need, tends in consequence of repetition, to relieve that need by the process of least effort.

In other words, the capacity of the various stimuli in the external situation to elicit responses from the animal becomes changed and organized in a fashion prescribed by a definite law. The law, namely, that the behavior of the animal, in relieving its need, shall become the minimum possible.

In 1937, R. H. Waters repeated Gengerelli's maze experiments utilizing both rats and human subjects. His goal was to test three related but somewhat different hypotheses, or 'Laws of the Principle of Least Effort' that had been recently proposed in experimental psychology: (1) R. H. Wheeler's (1929) Law of Least Action; (2) J. A. Gengerelli's (1930) Principle of Maxima and Minima (described above), and (3) L. S. Tsai's (1932) Law of Minimum Effort. Waters finds some positive aspects to both Gengerelli's and Tsai's formulations, but because he recognizes that behavioral variability will be contingent upon physiological and cognitive differences between organisms, external constraints, and the like, he prefers Tsai's Law of Minimum Effort. Interestingly, George Zipf (1902 - 1950) would later take 'Principle' from Gengerelli's formulation, 'Least' from Wheeler's formulation, and 'Effort' from Tsai's formulation to concoct the 'Principle of Least Effort' in 1949, apparently unaware that Malinowski had used the term to refer to PEM 27 years earlier.

Nevertheless, while recognizing some positive aspects to Tsai's Law of Minimum Effort, Waters also recognized some limitations in that formulation. One of these is the dimension of pain. Specifically, even rats may not choose a path of least resistance or greatest energetic efficiency if that path causes pain. In contrast, non-living phenomenon such as water flowing down a mountain may follow a path of least resistance, but in doing so feels no pain on its journey downward. The water has no other incentive or built-in behavioral capabilities to choose its path down the mountain. Waters has therefore challenged the notion that the living and nonliving are equivalent dimensions that can be explained by a single, overarching 'law'. But the energy maximizing hypothesis is too strong, so Waters 
(1937:16-17) suggests simply incorporating the pain dimension into the minimum effort equation:

Gengerelli points out that by taking the wall these animals avoided the pain consequent upon bumping into these obstacles. This is clearly an instance showing that, if the pathway of minimum effort involves painful stimulation to the animal, then that pathway will be avoided. It might be suggested, however, that the Law of Minimum Effort be so interpreted as to include the pain dimension, that is, that that pathway involving least painful stimulation will be taken. If this were done, then we would be able to say that the Law of Minimum Effort, with the limitations already mentioned, holds for the following dimensions: distance, time, effort, and pain.

We can sense in this passage an attempt to salvage a doomed scientific postulate. Waters previously noted that dimensions such as pain were unquantifiable, and even if it could be quantified, it would be so variable amongst individuals that the dimension would remain largely unknowable. And yet Waters insisted on making living dimensions such as pain part of what he would call a Law of Minimum Effort. Waters writings also beg the questions: If pain influences a rat's decision regarding whether or not to choose a path of least resistance or least expenditure of energy, what about other dimensions that must be taken into account to understand human behavior such as love, desire, hate, jealousy, sympathy, apathy and the like? Can we quantify all of those dimensions? How, then, would this Law be applied to human behavior? Ironically, Waters all but answered these questions - namely that the Law of Minimum Effort does not apply to human behavior.

In the case of the human subjects no single explanation seems possible, due to the reasons they gave for taking the several paths. If they did manifest a preference, regardless of the number of turns required by it, they usually claimed that it seemed shorter or easier. However, many subjects were activated by other motives, such as the desire to go as many different ways as possible, the thought that the aim of the test was to see how many ways they could find, the fear that they would lose their way if they tried another, and so on... With such maze structure and with such a welter of motives, each individual case becomes a law unto itself and thus prohibits, in our situations at least, the formulation of any single explanatory principle (Waters 1937:17-18).

Waters then notes that not only does his research indicate that the Law of Minimum Effort does not apply to human behavior, but others had already noted as such:

Tolman ...points out that, if there is some physiological principle, some principle of least effort, at the basis of behavior, a knowledge of this fact is relatively barren. "For, given the present parlous state of our physiological knowledge, it appears that the mere fact of such a principle allows us to predict nothing beforehand and prior to concrete behavior experiments". Now, in the first place, he is not in reality telling us to "go to" with our attempts at demonstrating this principle... (Waters, 1937:18).

Despite evidence that the PEM framework was untenable as an explanation of human action, the model became the ultimate panacea of explanation in the universe with the writings of George Zipf in the 1940s. For Zipf, everything in the universe boiled down to the tri-fold phenomena of any real consequence: matter (or energy or action), time, and space (including distance). These interact to create the one true law that unites the entire spectrum of the universe, the living and the nonliving. 
In 1942, Zipf was unconcerned about the exact title of his unifying principle. For him, least action, minimum effort and energetic efficiency were essentially synonymous terms.

As to the verbal pitfall, we must remember that the minimum of least-action can be described equally well by using other words....Yet a different verbal label will not necessarily entail the presence of a different minimum.

There are further variants of least-action, such as least-work, least-labor, or, in more disguised form, the economical use of energy... Nevertheless fundamental drives remain fundamental drives, regardless of verbal dressing (Zipf 1942:50-51).

The most fundamental feature of the universe for Zipf is the fact that as time passes, matter moves through space. Once this fundamental fact is realized, then all phenomena can be explained with reference to it. We must further realize that of the tripartite phenomena, matter (or action) (or energy) is the most important. Once these salient features of the universe are realized, the only thing remaining is to have faith that these principles guide every action in the universe, the living as well as the nonliving. But for Zipf, it was not faith to believe in these principles - it was simply a rational, self-evident conclusion to any rightthinking person.

It is commonly assumed by natural scientists that there is a "unity of nature" in the sense of a "continuity of natural law." In other words, it is assumed that all of nature (i.e., "the entire universe") is organized as a single great unit according to a single body of law which operates at all times and at all places throughout the entire universe. According to this assumption, the same general natural law that governs the structure and behavior of astronomical bodies governs also the structure and behavior of our planet, of life on our planet, and, indeed, of even the smallest minutiae of living activity including the most subtle emotional and intellectual elaborations of human mind (Zipf, 1942:48).

Zipf contrasts this right-way of thinking with those who believe that variability in behavior does not necessarily reflect a deep-rooted, fundamental law of nature. To Zipf, it is the ignorant who think that nature can organize the living in myriad of ways that show fits of randomness.

In this argument about the existence of social laws, we notice that those who assume the unity of nature, or the continuity of natural law, conclude that there are social laws (and hereinafter we shall call them the natural social scientists). By the same token, those who believe that there are no such things as social laws, automatically (though perhaps tacitly and unwittingly) conclude that there is no such thing as a unity of nature. These opponents of natural law in the social field are often referred to as "political theologians" and "economic romanticists", quite analogous to the quacks in medical science.... They might be God who, by definition, decides what the natural codes are to be (Zipf, 1942:52).

But unlike the "quacks" in the medical profession, Zipf understands that his assumption must be borne out with empirical research. Thus, he confidently boasts:

The unity of nature, the continuity of natural law, the universal principle of least- action can be established only by rigorous empiric research before whose decision all minds must bow(Zipf, 1942:52-53). 
Zipf appeals to the Capitalist economic writings concerning labor relations for support, and in the process, sets the stage for what would become known as materialist models in archaeology and patch choice models within an optimal foraging framework in biology and archaeology - namely that people must organize themselves on the landscape with an eye toward least-effort or least-action.

If we assume in the company of economists that man tries to save labor (i.e., is motivated by the consideration of least-action) in all his activities, we must conclude that he will automatically try to save labor in his exploitation of the raw materials of nature, not only in the procuring and manufacture of raw materials into finished goods, but also in his distribution and consumption of the same (Zipf 1942:53-54).

But Zipf doesn't stop there. Like Alfred Lotka before him, Zipf enters into the metaphysical. Perhaps, he notes, we will one day determine that the human soul, if it exists, operates under the Principle of Least Effort as well. And if that is the case, then Zipf has explained the human soul mathematically, and in the process, perhaps, found God.

Thus, for example, if man has an immortal soul, as many believe, then, according to our argument, that immortal soul will exist in obedience to the principle of least-action. And whether or not man has such a soul may very well be decided one way or another by scientific inquiry, perhaps even sooner than we think (Zipf 1942:62).

\section{Concluding remarks: The future of Primitive Economic Man and nutritional ecology}

Hallowed with age, having been found helpful in one or many fields of inquiry, it has been the lot of every good idea to be borrowed and reborrowed time and time again, always retaining the essence of its old identity, but adding new shades of meaning or losing old ones with every borrowing (Hodgen, 1964).

Many of the central ideas embedded in optimization frameworks were first developed in Antiquity two millennia ago. These include individual self-interest, ideal types, optimal states, and least effort. The mathematical representations of principles related to maxima and minima, least-action, and conservation of the active force or energy, developed primarily in the 17th and 18th centuries to describe the movements and interactions of matter in the nonliving world, deeply influenced deductively-based ideas about human nature and human health patterns in the 19th and 20th centuries. Many of these latter ideas have remained intact in the PEM or optimization frameworks in 21 st century archaeology (e.g., Broughton et al., 2011). PEM was buried in the nutrition sciences 80 years ago, yet schemes involving protein pills and bad carbohydrates continue to capture the imagination into the $21^{\text {st }}$ century (e.g., see Carpenter, 1994 for protein supremacy arguments reminiscent of Liebig's methods from the middle 1800s).

Why do PEM models continue to be so attractive to many researchers, even after it has been shown that they produce marginal results in discipline after discipline? There could be several reasons for PEM's survival in archaeology. First, there is a certain ring of truth about least effort behaviors. For examples, foragers walking across the landscape undoubtedly at times (but not always) chose a path of least resistance; and specific technological developments undoubtedly became fixed in human societies because they offered greater 
efficiency in procuring and/or processing foods. Another attractive component to PEM is that the models derived from its principles often develop into mathematical formulations that are tested with statistics. This gives an aura of "hard science" to these models; in short, it looks like good science. Lastly, these models are well suited for the deductive nature of the scientific study of archaeology that students are told in graduate school they must conform with in order to do 'good science' and be 'good scientists'.

Although humans occasionally make choices based on energetic efficiency, it has never been shown that (a) energetic efficiency is of primary concern to human decision-making; and (b) decisions repeatedly based on energetic efficiency would result in greater selective fitness over time. In contrast, it has been repeatedly shown that humans make decisions about what to eat and what not to eat based on a multitude of reasons (such as taste preferences, taboos and the like) that have nothing to do with energetic efficiency in either the procurement or consumption of those foods. Ethnographic research on a multitude of foraging societies across the globe do not suggest that hunter-gatherers were in a perpetual state of famine or chronic energy deficiency (e.g., Lee and Daly, 2006b; Lee and Devore, 1968); nor were their actions overly concerned with seeking more efficient or most efficient methods to capture and consume calories. Past societies, like those documented ethnographically, likely had a multitude of choices - about what to eat and when and where to eat it. And in many environments, both past and present, there were likely a multitude of ways to procure the nutrients to sustain the next generation, none of which necessitated 'optimal' behaviors in terms of either macronutrient or micronutrient intake. And when it comes to selective fitness, those human foragers who were only concerned about procuring calories with the least effort would likely find themselves outcompeted and soon extinct by others who chose (probably unwittingly) a diet that resulted in the consistent consumption of a wide diversity of all the essential nutrients necessary to sustain mother and child.

One of the most ironic factors about PEM modeling in archaeology and its reliance on the deductive method is that the concept of Darwinian selective fitness developed primarily through inductive rather than deductive research. It is difficult to see how deductively based research can be considered 'superior' to inductively based research, or, worse yet, how deductively based research can be considered 'more scientific' in the sense that all research should be conducted under the umbrella of a deductive model. I think that most of archaeology's fact-building and learning continues to occur through the "Well I'll be damned" factor. Inductively based archaeological research, whether through new excavations, experimental archaeology, the development of new technologies applied to old data, and the interpretations resulting from this research often result in new discoveries that teach us more about the who, what, where, when, and why of past societies than deductive approaches. PEM modeling is a good example. It has been used and abused in multiple disciplines for centuries, and in those disciplines concerned with explaining human behavior (economics, psychology, sociology, and anthropology) it has proven to provide marginal results at best. Deductively based approaches have certainly spurred new methods and new ways of looking at data, but the vilification of inductive research in some archaeology circles is unjustified. It is rather astonishing just how much we have actually learned about past societies through strict inductive research.

Nutritional ecology is primarily a tool to conduct inductive research and to generate inductively-based interpretations and explanations of the past, but it does have its 
predictive capacities as well. It is a model designed to interpret correlations between demographic trends and dietary intake. For example, nutritional ecology has been used in the study of Neanderthal extinction in order to model and interpret whether dietary differences between modern human and Neanderthal populations could have led to differences in the survival rates of women and children in these two populations (Hockett and Haws, 2003, 2005). Nutritional ecology essentially asks: did modern humans have a selective advantage over Neanderthals due to greater consistency in essential nutrient intake in the modern human populations? The framework may have relevance for understanding these specific correlations at both the micro-and macro-scales of analysis, although no assumption is made that macro-scale patterns are mere reflections of micro-scale actions. Quantum physics, or the theory of the very small, may hold lessons in the danger of linking micro-scale actions to macro-scale patterns. Nutritional ecology, however, can also inform on what is possible in human dietary choice (e.g., Hockett, 2011).

In certain cases, differences in energy consumption (or chronic energy deficiency) may help to understand demographic shifts in the archaeological record, but the nutritional ecology framework addresses macronutrient and micronutrient deficiencies or over-consumption equally well, so it is a more 'covering' paradigm than the PEM framework. For those who choose to focus on inductive research and incorporate current knowledge about the effects of essential nutrients on mortality and fertility trends, nutritional ecology offers an alternative to PEM in archaeological theory building.

\section{Acknowledgment}

I thank Vana Persen for inviting me to contribute to this volume, as well as the editors at InTech for their courage in publishing this piece. The origin of this essay came to me in 2006. Over the past five years, I have had numerous conversations about this essay with a variety of researchers, all of which helped me to focus my manuscript. Principal among them, although none of them necessarily agree with its conclusions, were Jonathan Haws, Lee Lyman, Ted Goebel, Kelly Graf, and Tim Murphy. I graciously thank them all.

\section{References}

Adams, R. (1978). Man, energy, and anthropology: I can feel the heat, but where's the light? American Anthropologist, 80, 297-309.

Alvey, J. (2004). The hidden theology of Adam Smith: a belated reply to Hill. European Journal of the History of Economic Thought, 11, 623-628.

Arnott, M. (1976). Gastronomy: The Anthropology of Food and Food Habits. Chicago, Aldine.

Ashworth, C., \& Antipatis, C. (2001). Micronutrient programming of development throughout gestation. Reproduction, 122, 527-535.

Atwater, W. (1887). How food nourishes the body. Century Magazine, 34, 237-251.

Atwater, W. (1888). What we should eat. Century Magazine, 36, 257-264.

Baker, F. (1890). The ascent of man. The American Anthropologist, 3, 297-320.

Beckert, J. (1996). What is sociological about economic sociology? Uncertainty and the embeddedness of economic action. Theory and Society, 25, 803-840.

Bergstrom, T. (2002). Evolution of social behavior: individual and group selection. Journal of Economic Perspectives, 16, 67-88. 
Binford, L. (1972). An Archaeological Perspective. New York, Seminar Press.

Binford, L. (2001). Constructing Frames of Reference. Berkeley, University of California Press.

Binford, L., \& Binford, S. (1968). New Perspectives in Archeology. Chicago, Aldine.

Boas, G. (1948). Essays on Primitivism and Related Ideas in the Middle Ages. Baltimore, The Johns Hopkins Press.

Brooks, D. \& McLennan, D. (2002). The Nature of Diversity: An Evolutionary Voyage of Discovery. Chicago: University of Chicago Press.

Broughton, J., \& Bayham, F. (2002). Showing off, foraging models, and the ascendance of large game hunting in the California Middle Archaic. American Antiquity, 68, 783789.

Broughton, J., Cannon, M., Bayham, F., \& Byers, D. (2011). Prey body size and ranking in zooarchaeology: theory, empirical evidence, and applications from the northern Great Basin. American Antiquity, 76, 403-428.

Brown, H. (1936). The utilitarian motive in the age of Descartes. Annals of Science, 1, 182-192.

Burnett, S. (1892). The modern apotheosis of nature. American Anthropologist, 5, 247-262.

Campbell, D. (1987). A test of the energy maximization premise of optimal foraging theory. In A. Kamil, Krebs, J., \& Pulliam, H. (Eds), Foraging Behavior (pp.143-171). New York, Plenum Press.

Carpenter, K. (1994). Protein and Energy: A Study of Changing Ideas in Nutrition. Cambridge, Cambridge University Press.

Carpenter, K. (2003a). A short history of nutritional science: part 1 (1785-1885). Journal of Nutrition, 133, 638-645.

Carpenter, K. (2003b). A short history of nutritional science: part 2 (1885-1912). Journal of Nutrition, 133, 975-984.

Carpenter, K. (2003c). A short history of nutritional science: part 3 (1912-1944). Journal of Nutrition, 133, 3023-3032.

Carpenter, K., Harper, A., \& Olson, R. (1997). Experiments that changed nutritional thinking. Journal of Nutrition, 127, 1017S-1053S.

Carruthers, B. (1994). Homo economicus and Homo politicus: non-economic rationality in the early 18th century London stock market. Acta Sociologica, 37, 165-194.

Christesen, P. (2003). Economic rationalism in fourth-century BCE Athens. Greece \& Rome, 50, 31-56.

Clayton, F., Sealy, J., \& Pfeiffer, P. (2006). Weaning age among foragers at Matjes River Rock Shelter, South Africa, from stable nitrogen and carbon isotope analyses. American Journal of Physical Anthropology, 129, 311-317.

Closson, C. (1896). Social selection. The Journal of Political Economy, 4, 449-466.

Cohen, L. (1936). Descartes and Henry More on the beast-machine - a translation of their correspondance pertaining to animal automatism. Annals of Science, 1, 48-61.

Counihan, C. (1999). The Anthropology of Food and Body: Gender, Meaning, and Power. New York, Routledge.

Cramer, C. (2002). Homo economicus goes to war: Methodological individualism, rational choice and the political economy of war. World Development, 30, 1845-1864.

Crawford, M., Bloom, M., Broadhurst, C., Schmidt, W., Cunnane, S. Galli, C. et al. (1999). Evidence for the unique function of DHA during the evolution of the modern hominid brain. Lipids, 34, S39-S47. 
De Lapouge, G., \& Closson, C. (1897). The fundamental laws of anthropo-sociology. The Journal of Political Economy, 6, 54-92.

Doucouliagos, C. (1994). A note on the evolution of Homo economicus. Journal of Economic Issues, 3, 877-883.

Dutcher, R. A., Pierson, E., Biester, A. (1919). The antiscorbutic properties of raw lean beef. Science, 50, 184-185.

Eaton, S. B., Shostak, M., \& Konner, M. (1988). The Paleolithic Prescription: A Program of Diet E Exercise and a Design for Living. New York, Harper \& Row.

Elvehjem, C. A. (1949). Seven decades of nutrition research. Science, 109, 354-358.

Emlen, J. M. (1966). The role of time and energy in food preference. The American Naturalist, 100, 611-617.

Emlen, J. M., \& Emlen, M. G. R. (1975). Optimal choice in diet: test of a hypothesis. The American Naturalist, 109, 427-435.

Euler, L. (1795/1997). Letters of Euler to a German Princess, Volume 1. Bristol, Thoemmes Press.

Evans, H., \& Bishop, K. S. (1922). On the existence of a hitherto unrecognized dietary factor essential for reproduction. Science, 56, 650-651.

Evans, H., Burr, G. (1925). The anti-sterility vitamine fat soluble E. Proceedings of the National Academy of Sciences, 11, 334-341.

Fall, C., Chittaranjan, S., Rao, S., Davies, A., Brown, N., \& Farrant, J. (2003). Micronutrients and fetal growth. Journal of Nutrition, 133, 1747S-1756S.

Ferguson, J. (2000). Economics and barbarism: an anthropological comment on Pearson's "Homo economicus". History of Political Economy, 32, 991-998.

Foley, R. (1985). Optimality theory in anthropology. Man, 20, 222-242.

Friend, M. (1699). A letter from Mr. John Friend to Dr. Sloane, dated Oxon. Jul. 26. Concerning an hydrocephalus. Philosophical Transactions, 21, 318-322.

Funk, C. (1925). The nomenclature of the vitamines. Science, 62, 157-158.

Funk, C. (1926). Who discovered vitamines? Science, 63, 455-456.

Funk, C., Dubin, H. (1920). The vitamine requirements of the rat on diets rich in protein, carbohydrate, and fat respectively. Science, 52, 447-448.

Gaskin, J. C. A. (1996). Introduction. In T. Hobbes, Leviathan (pp. xi-xliii). Oxford, Oxford University Press.

Gengerelli, J. (1930). The principle of maxima and minima in animal learning. Journal of Comparative Psychology, 11, 193-236.

Gerth, H. H., \& Mills, W. (1946). From Max Weber: Essays in Sociology. New York, Oxford University Press.

Gibbs, F. W. (1951). Peter Shaw and the revival of chemistry. Annals of Science, 7, 211-237.

Godkin, E. L. (1891). The economic man. The North American Review, 153, 491-503.

Gould, S. (1981). The Mismeasure of Man. New York, W. W. Norton \& Company.

Gray, R. (1987). Faith and foraging: a critique of the "paradigm argument from design". In A. Kamil, Krebs, J., \& Pulliam, H. (Eds.), Foraging Behavior (pp. 69-140). New York, Plenum Press.

Grey, V. (1982). The Chemist Who Lost His Head: The Story of Antoine Laurent Lavoisier. New York: Coward, McCann \& Geoghegan.

Harding, R., \& Teleki, G. (1981). Omnivorous Primates: Gathering and Hunting in Human Evolution. New York, Columbia University Press. 
Harper, A. (1997). Liebig's concept of nutritional adequacy challenged. Journal of Nutrition, 27, 1027S-1029S.

Harris, M., \& Ross, E. (1987). Food and Evolution: Toward a Theory of Human Food Habits. Philadelphia, Temple University Press.

Hartog, P. (1941). The newer views of Priestly and Lavoisier. Annals of Science, 5, 1-56.

Heider, K. (1976). Dani sexuality: a low energy system. Man, 11, 188-201.

Helmholz, H. (1861). On the application of the law of the conservation of force to organic nature. Proceedings of the Royal Society, 3, 347-357.

Henrich, J., Boyd, R., Bowles, S., Camerer, C., Fehr, E., Gintis, H., McElreath, R. (2001). In search of Homo economicus: behavioral experiments in 15 small-scale societies. American Economic Review, 91, 73-78.

Hill, L. (2004). Further reflections on the 'hidden theology' of Adam Smith. European Journal of the History of Economic Thought, 11, 629-635.

Hirsch, P., Michaels, S., \& Friedman, R. (1987). "Dirty hands" versus "clean models": Is sociology in danger of being seduced by economics? Theory and Society, 16, 317-336.

Hobbes, T. (1651/1998). Leviathan. Oxford, Oxford University Press.

Hockett, B. (2011). The consequences of Middle Paleolithic diets on pregnant Neanderthal women. Quaternary International, in press.

Hockett, B., \& Haws, J. 2003. Nutritional ecology and diachronic trends in Paleolithic diet and health. Evolutionary Anthropology, 12, 211-216.

Hockett, B., \& Haws, J. (2005). Nutritional ecology and the human demography of Neandertal extinction. Quaternary International, 137, 21-34.

Hodgen, M. (1964). Early Anthropology in the Sixteenth and Seventeenth Centuries. University of Pennsylvania Press, Philadelphia.

Hume, D. (1748/1955). An Inquiry Concerning Human Understanding. Indianapolis, The Bobbs-Merrill Company, Inc.

Ingold, T. (1992). Foraging for data, camping with theories: hunter-gatherers and nomadic pastoralists in archaeology and anthropology. Antiquity, 66, 790-803.

Ingold, T. (2000). The Perception of the Environment: Essays in Livlihood, Dwelling and Skill. London, Routledge.

Jeans, J. (1907). An Elementary Treatise on Theoretical Mechanics. Boston, Ginn \& Company.

Jenike, M. (2001). Nutritional ecology: diet, physical activity and body size. In C. PanterBrick, R. Layton \& P. Rowley-Conwy (Eds.), Hunter-Gatherers: An Interdisciplinary Perspective (pp.205-238). Cambridge, Cambridge University Press.

Jourdain, P. (1913). The Principle of Least Action. Chicago, The Open Court Publishing Company.

Kamil, A., J. Krebs \& H. Pulliam, 1987. Foraging Behavior. New York, Plenum Press.

Keene, A. (1983). Biology, behavior, and borrowing: a critical examination of optimal foraging theory in archaeology. In J. Moore \& A. Keene (Eds.), Archaeological Hammers and Theories (pp. 137-155). Orlando, Academic Press.

Kehoe, A., \& Giletti, D. (1981). Women's preponderance in possession cults: the calciumdeficiency hypothesis extended. American Anthropologist, 83, 549-561.

Kroeber, A. (1917). The superorganic. American Anthropologist, 19, 163-214.

Lee, R., Daly, R. (2006a). The Cambridge Encyclopedia of Hunters and Gatherers. Cambridge, Cambridge University Press. 
Lee, R., \& Daly, R. (2006b). Foragers and others. In R. Lee \& R. Daly (Eds.), The Cambridge Encyclopedia of Hunters and Gatherers (pp. 1-19). Cambridge, Cambridge University Press.

Lee, R., \& DeVore, I. (1968). Man the Hunter. Chicago, Aldine Publishing Company.

Leersum, E. C. (1929). Terminology of "vitamin B". Science, 69, 166-167.

Liebig, J. (1842/1964). Animal Chemistry or Organic Chemistry in its Application to Physiology and Pathology. New York, Johnson Reprint Corporation.

Little, M., Morren, G. (1976). Ecology, Energetics, and Human Variability. Dubuque, Wm. C. Brown Company.

Locke, J. (1690/1980). Second Treatise on Government. Indianapolis, Hackett Publishing Company.

Lotka, A. (1922). Contribution to the energetics of evolution. Proceedings of the National Academy of Sciences, 8, 147-151.

Lotka, A. (1925). Elements of Physical Biology. Baltimore, Williams \& Wilkins Company.

Lotka, A. (1945). The law of evolution as a maximal principle. Human Biology, 17, 185.

Lovejoy, A., \& Boas, G. (1935/1997). Primitivism and Related Ideas in Antiquity. Baltimore, Johns Hopkins University Press.

MacArthur, R., \& Pianka, E. (1966). On optimal use of a patchy environment. The American Naturalist, 100, 603-609.

Malinowski, B. (1922/1932). Argonauts of the Western Pacific: An Account of Native Exterprise and Adventure in the Archipelagoes of Melanesian New Guinea. London, George Routledge \& Sons, Ltd.

Mallery, G. (1888). Manners and meals. The American Anthropologist, 1, 193-208.

Martin, J. (1983). Optimal foraging theory: a review of some models and their applications. American Anthropologist, 85, 612-629.

Martin, J. (1985). More on optimal foraging theory. American Anthropologist, 87, 649-650.

Mason, O. T. (1894). Migration and the food quest: a study in the peopling of America. American Anthropologist, 7, 275-292.

McCollum, E. V., \& Davis, M. (1915). The nature of the dietary deficiencies of rice. Journal of Biological Chemistry, 23, 181-230.

Mill, J. S. (1836/1967). On the definition of political economy and on the method of investigation proper to it. In J. M. Robson (Ed.), Collected Works of John Stuart Mill, Volume IV (pp. 309-339). Toronto, Toronto University Press.

Mill, J. S. (1848/2004). Principles of Political Economy. New York, Prometheus Books.

Mitchell, H. H. (1922). The necessity of balancing dietaries with respect to vitamines. Science, 56, 34-37.

Moses, B. (1894). The nature of sociology. The Journal of Political Economy, 3, 24-38.

Myers, C. N., Voegtlin, C. (1920). The chemical isolation of vitamines. Proceedings of the National Academy of Sciences, 6, 3-4.

Nasmyth, A. (1848). On the human mouth. Journal of the Ethnological Society of London, 1, 192209.

Newman, M. (1962). Ecology and nutritional stress in man. American Anthropologist, 64, 2234.

Newton, I. (1687/1999). The Mathematical Principles of Natural Philosophy. Berkeley: University of California Press. 
Nieli, R. (1986). Spheres of intimacy and the Adam Smith problem. Journal of the History of Ideas, 47, 611-624.

Nippel, W. (2000). From agrarian history to cross-cultural comparisons: Weber on GrecoRoman Antiquity. In S. Turner (Ed.), The Cambridge Companion to Weber (pp.240255). Cambridge, Cambridge University Press.

North American Review (1842). Review of Animal chemistry, or organic chemistry in its application to physiology and pathology. The North American Review, 55, 462-500.

Ogden, H. V. S. (1940). The state of nature and the decline of Lockian political theory in England. The American Historical Review, 46, 21-44.

Ostwald, W. (1910). Natural Philosophy. New York, Henry Holt and Company.

Pearson, H. (2000). Homo economicus goes native, 1859-1945: the rise and fall of primitive economics. History of Political Economy, 32, 933-989.

Peart, S., Levy, D. (2004). Sympathy and its discontents: 'greatest happiness' versus the 'general good'. European Journal of the History of Economic Thought, 11, 453-478.

Persky, J. (1995). The ethology of Homo economicus. Journal of Economic Perspectives, 9, 221231.

Pierce, G. J., Ollason, J. G. (1987). Eight reasons why optimal foraging theory is a complete waste of time. Oikos, 49, 111-118.

Powell, J. W. (1888). Competition as a factor in human evolution. The American Anthropologist,1, 297-323.

Prieto, J. (2004). Bernard Mandeville's heir: Adam Smith or Jean Jacques Rousseau on the possibility of economic analysis. European Journal of the History of Economic Thought, 11, 1-31.

Pyke, G. H., Pulliam, H. R., Charnov, E. L. (1977). Optimal foraging: a selective review of theory and tests. The Quarterly Review of Biology, 52, 137-154.

Quin, P. J. (1959). Foods and Feeding Habits of the Pedi with Special Reference to Identification, Classification, Preparation and Nutritive Value of the Respective Foods. Johannesburg, Witwatersrand University Press.

Radin, P. (1970). Introduction to the Torchbook edition. In E. Tylor, The Origins of Culture (pp. ix-xv). Gloucester, Peter Smith.

Ramikrishnan, U., Manjrekar, R., Rivera, J., Gonzales-Cossio, T., \& Martorell, R. (1999). Micronutrients and pregnancy outcome: a review of the literature. Nutrition Research, 19, 103-159.

Richards, A. (1932). Hunger and Work in a Savage Tribe: A Functional Study of Nutrition Among the Southern Bantu. London, George Routledge \& Sons, Ltd.

Robinson, L. (1894). The primitive child. The North American Review, 159, 467-479.

Robson, A. (2002). Evolution and human nature. Journal of Economic Perspectives, 16, 89-106.

Roth, E. (2004). Culture, Biology, and Anthropological Demography. Cambridge, Cambridge University Press.

Rousseau, J.-J. (1762/1968). The Social Contract. London, Penguin Books.

Rousseau, J.-J. (1755/2002). The Social Contract and The First and Second Discourses. Princeton, Yale University Press.

Rushton, J. (2004). Genetic and environmental contributions to pro-social attitudes: a twin study of social responsibility. Proceedings of the Royal Society of London B, 271, 25832585. 
Schluter, D. (1981). Does the theory of optimal diets apply in complex environments? The American Naturalist, 118, 139-147.

Schoener, T. (1987). A brief history of optimal foraging theory. In A. Kamil, J. Krebs \& H. Pulliam (Eds.), Foraging Behavior (pp. 5-67). New York, Plenum Press.

Schwarcz, H., \& Schoeninger, M. (1991). Stable isotope analysis in human nutritional ecology. Yearbook of Physical Anthropology, 34, 283-321.

Sih, A., \& Milton, K. (1985). Optimal diet theory: should the !Kung eat mongongos? American Anthropologist, 87, 395-401.

Sloane, H. (1699). Some observations made at a meeting of the Royal Society, concerning some wonderful contrivances of nature in a family of plants in Jamaica, to perfect the individuum, and propagate the species, with several instances analogous to them in European vegetables. Philosophical Transactions, 21, 113-120.

Smith, A. (1776/1963). An Inquiry into the Nature and Causes of the Wealth of Nations. New York, P. F. Collier \& Son Corporation.

Smith, C. (1998). The Science of Energy: A Cultural History of Energy Physics in Victorian Britain. Chicago, University of Chicago Press.

Steenbock, H. (1918). Vitamines and nutrition. Science, 47, 119.

Stini, W. (1981). Evolutionary implications of changing nutritional patterns in human populations. American Anthropologist, 73, 1019-1030.

Stoczkowski, W. (2002). Explaining Human Origins: Myth, Imagination and Conjecture. Cambridge, Cambridge University Press.

Stuart, H. (1895). The hedonistic interpretation of subjective value. The Journal of Political Economy, 4, 64-84.

Thaler, R. (1999). Mental accounting matters. Journal of Behavioral Decision Making, 12, 183206.

Thaler, R. (2000). From Homo economicus to Homo sapiens. Journal of Economic Perspectives, 14, 133-141.

Thompson, J., \& Manoer, M. (2006). Nutrition: An Applied Approach. San Francisco, Pearson.

Thrupp, J. (1867). British superstitions as to hares, geese, and poultry. Transactions of the Ethnological Society of London, 5, 162-167.

Tugwell, R. (1922). Human nature in economic theory. The Journal of Political Economy, 30, 317-345.

Tylor, E. (1871/1970). The Origins of Culture. Gloucester, Peter Smith.

Underwood, J. (1975). Biocultural Interactions and Human Variation. Dubuque, Wm. C. Brown Company.

Vayda, A. (1970). On the nutritional value of cannibalism. American Anthropologist, 72, 1462-1463.

Wallis, J. (1700-1701). A letter of Dr. Wallis to Dr. Tyson, concerning mens feeding on flesh. Philosophical Transactions, 22, 769-785.

Waterman, A. M. C. (2002). Economics as theology: Adam Smith's Wealth of Nations. Southern Economic Journal, 68, 907-921.

Waters, R. H. (1937). The principle of least effort in learning. Journal of General Psychology, 16, 3-20.

Weber, M. (1922/1978). Economy and Society: An Outline of Interpretive Sociology. Berkeley, University of California Press. 
Weber, M. (1915/1946). From Max Weber: Essays in Sociology. New York, Oxford University Press.

Weber, M. (1920). General Economic History. London, George Allen \& Unwin Ltd.

White, L. (1949). The Science of Culture. New York, Grove Press, Inc.

White, L. (1959). The Evolution of Culture: The Development of Civilization to the Fall of Rome. New York, McGraw-Hill.

Wing, E., Brown, A. (1979). Paleonutrition: Method and Theory in Prehistoric Foodways. New York, Academic Press.

Winterhalder, B., \& Smith, E. (2000). Analyzing adaptive strategies: human behavioral ecology at twenty-five. Evolutionary Anthropology, 9, 51-72.

Wolf, G., Carpenter, K. (1997). Early research into the vitamins: the work of Wilhelm Stepp. Journal of Nutrition, 127, 1255-1259.

Zafirovski, M. (2000). The rational choice generalization of neoclassical economics reconsidered: any theoretical legitimation for economic imperialism? Sociological Theory, 18, 448-471.

Zipf, G. (1942). The unity of nature, least-action, and natural social science. Sociometry, 5, 4862.

Zipf, G. (1949/1965). Human Behavior and the Principle of Least Effort: An Introduction to Human Ecology. New York, Hafner.

Zouboulakis, M. (2001). From Mill to Weber: the meaning of the concept of economic rationality. European Journal of the History of Economic Thought, 8, 30-41. 


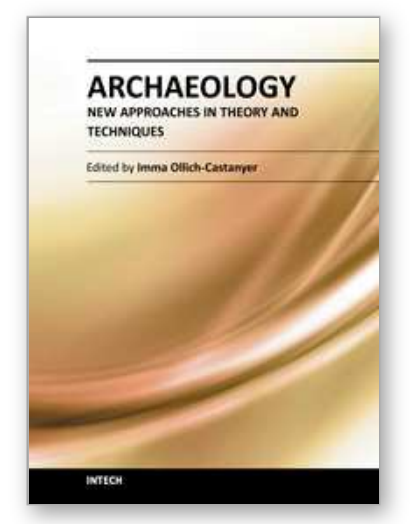

\author{
Archaeology, New Approaches in Theory and Techniques \\ Edited by Dr. Imma Ollich-Castanyer
}

ISBN 978-953-51-0590-9

Hard cover, 292 pages

Publisher InTech

Published online 09, May, 2012

Published in print edition May, 2012

The contents of this book show the implementation of new methodologies applied to archaeological sites. Chapters have been grouped in four sections: New Approaches About Archaeological Theory and Methodology; The Use of Geophysics on Archaeological Fieldwork; New Applied Techniques - Improving Material Culture and Experimentation; and Sharing Knowledge - Some Proposals Concerning Heritage and Education. Many different research projects, many different scientists and authors from different countries, many different historical times and periods, but only one objective: working together to increase our knowledge of ancient populations through archaeological work. The proposal of this book is to diffuse new methods and techniques developed by scientists to be used in archaeological works. That is the reason why we have thought that a publication on line is the best way of using new technology for sharing knowledge everywhere. Discovering, sharing knowledge, asking questions about our remote past and origins, are in the basis of humanity, and also are in the basis of archaeology as a science.

\title{
How to reference
}

In order to correctly reference this scholarly work, feel free to copy and paste the following:

Bryan Hockett (2012). Optimizing Energy - The Epistemology of Primitive Economic Man, Archaeology, New Approaches in Theory and Techniques, Dr. Imma Ollich-Castanyer (Ed.), ISBN: 978-953-51-0590-9, InTech, Available from: http://www.intechopen.com/books/archaeology-new-approaches-in-theory-andtechniques/optimizing-energy-the-epistemology-of-primitive-economic-man

\section{INTECH}

open science | open minds

\section{InTech Europe}

University Campus STeP Ri

Slavka Krautzeka 83/A

51000 Rijeka, Croatia

Phone: +385 (51) 770447

Fax: +385 (51) 686166

www.intechopen.com

\section{InTech China}

Unit 405, Office Block, Hotel Equatorial Shanghai

No.65, Yan An Road (West), Shanghai, 200040, China

中国上海市延安西路 65 号上海国际贵都大饭店办公楼 405 单元

Phone: $+86-21-62489820$

Fax: $+86-21-62489821$ 
(C) 2012 The Author(s). Licensee IntechOpen. This is an open access article distributed under the terms of the Creative Commons Attribution 3.0 License, which permits unrestricted use, distribution, and reproduction in any medium, provided the original work is properly cited. 